\title{
Understanding Potential Heavy Metal Contamination, Absorption, Translocation and Accumulation in Rice and Human Health Risks
}

\author{
Zuliana Zakaria ${ }^{1}$, Nur Syahirah Zulkafflee ${ }^{1}$, Nurul Adillah Mohd Redzuan ${ }^{1}$, Jinap Selamat ${ }^{1,2} \mathbb{D}$, \\ Mohd Razi Ismail ${ }^{3}$, Sarva Mangala Praveena ${ }^{2,4}$, Gergely Tóth ${ }^{5}$ (D) and Ahmad Faizal Abdull Razis 1,2,6,*(D)
}

check for

updates

Citation: Zakaria, Z.; Zulkafflee, N.S.; Mohd Redzuan, N.A.; Selamat, J.; Ismail, M.R.; Praveena, S.M.; Tóth, G.; Abdull Razis, A.F. Understanding Potential Heavy Metal

Contamination, Absorption, Translocation and Accumulation in Rice and Human Health Risks. Plants 2021, 10, 1070. https://doi.org/ $10.3390 /$ plants10061070

Academic Editor: Adriano Sofo

Received: 16 January 2021

Accepted: 2 March 2021

Published: 26 May 2021

Publisher's Note: MDPI stays neutral with regard to jurisdictional claims in published maps and institutional affiliations.

Copyright: (c) 2021 by the authors. Licensee MDPI, Basel, Switzerland. This article is an open access article distributed under the terms and conditions of the Creative Commons Attribution (CC BY) license (https:// creativecommons.org/licenses/by/ $4.0 /)$.
1 Department of Food Science, Faculty of Food Science and Technology, Universiti Putra Malaysia, UPM Serdang 43400, Selangor, Malaysia; zulianaz@moh.gov.my (Z.Z.); nursyahirahzulkafflee@gmail.com (N.S.Z.); dillaredzuan94@gmail.com (N.A.M.R.); sjinap@gmail.com (J.S.)

2 Laboratory of Food Safety and Food Integrity, Institute of Tropical Agriculture and Food Security, Universiti Putra Malaysia, UPM Serdang 43400, Selangor, Malaysia; smpraveena@upm.edu.my

3 Laboratory of Climate-Smart Food Crop Production, Institute of Tropical Agriculture and Food Security, Universiti Putra Malaysia, UPM Serdang 43400, Selangor, Malaysia; razi@upm.edu.my

4 Department of Environmental and Occupational Health, Faculty of Medicine and Health Sciences, Universiti Putra Malaysia, UPM Serdang 43400, Selangor, Malaysia

5 Department of Soil Science and Environmental Informatics, Georgikon Faculty, University of Pannonia, H-8360 Keszthely, Hungary; toth.gergely@agrar.mta.hu

6 Natural Medicines and Products Research Laboratory, Institute of Bioscience, Universiti Putra Malaysia, UPM Serdang 43400, Selangor, Malaysia

* Correspondence: madfaizal@upm.edu.my

\begin{abstract}
Rice is a worldwide staple food and heavy metal contamination is often reported in rice production. Heavy metal can originate from natural sources or be present through anthropogenic contamination. Therefore, this review summarizes the current status of heavy metal contamination in paddy soil and plants, highlighting the mechanism of uptake, bioaccumulation, and health risk assessment. A scoping search employing Google Scholar, Science Direct, Research Gate, Scopus, and Wiley Online was carried out to build up the review using the following keywords: heavy metals, absorption, translocation, accumulation, uptake, biotransformation, rice, and human risk with no restrictions being placed on the year of study. Cadmium $(\mathrm{Cd})$, arsenic $(\mathrm{As})$, and lead $(\mathrm{Pb})$ have been identified as the most prevalent metals in rice cultivation. Mining and irrigation activities are primary sources, but chemical fertilizer and pesticide usage also contribute to heavy metal contamination of paddy soil worldwide. Further to their adverse effect on the paddy ecosystem by reducing the soil fertility and grain yield, heavy metal contamination represents a risk to human health. An in-depth discussion is further offered on health risk assessments by quantitative measurement to identify potential risk towards heavy metal exposure via rice consumption, which consisted of in vitro digestion models through a vital ingestion portion of rice.
\end{abstract}

Keywords: heavy metals; rice; paddy soil; health risk assessment

\section{Introduction}

Because there is an increasing trend of population growth and demand of rice consumption, the use of an escalating number of pesticides by producers, in order to protect their crop, may influence the level of heavy metals in soils [1,2]. Heavy metal pollution on a paddy field has recently been of great concern as an environmental pollutant due to of its bioaccumulation in the environment and non-biodegradable properties [3]. Heavy metals have been commonly discussed as a potential pollutant in rice and it is classified as one of the major important toxic substances, due to its high potential risk to the ecosystem and human health [3]. 
The International Agency for Research on Cancer (IARC) (2012) [4] has classified arsenic (As), cadmium (Cd), chromium (Cr), and nickel (Ni) as group 1 carcinogen, since longterm exposure leads to increased risk of various type of cancer, including disruptions in tumor suppressor gene expression, damage repair processes, and enzymatic activities that are concerned in metabolism through oxidative damage [5]. By nature, heavy metals can be divided into two forms, which are organic and inorganic [6]. For example, inorganic As is more harmful than organic form due to the pentavalent inorganic compound of As that solubilizes in water to the weak acid form and produce arsenate [7] that affects people by inducing ground water contamination [8]. Heavy metals in the form of organic pollutant may gradually degrade into less harmful components through chemical or biological processes $[9,10]$. Environmental contamination of the biosphere with heavy metals have caused intensive agricultural and other anthropogenic activities and posed critical problems for safe use of agricultural land [11]. Agricultural soils are potentially contaminated with essential and nonessential heavy metals through existing agriculture practice with arbitrarily use of agrochemicals, such as pesticide and fertilizers, along with mechanical cultivation that change the speciation and the mobility of heavy metals [12,13].

In subsistence farms of Asia, there is a clear verification of the association between $\mathrm{Cd}$ poisoning and human renal dysfunction [14] and, certainly, rice has been recognized as one of the prime sources of $\mathrm{Cd}$ and $\mathrm{Pb}$ to human intake especially in Japan [15-18]. Plant organs have different abilities to adsorb, translocate, and accumulate heavy metals, and the speed and magnitude of these processes vary between plant species and cultivars [19-24]. Other than that, the adsorption and accumulation of heavy metals in soil is driven by soil properties, such as $\mathrm{pH}$, and the concentration of organic matter [25]. The direct transfer of heavy metals to human body from plant parts of interest is rice grain, which is an edible part for consumption that may cause a threat to human health [25].

Because heavy metals are proclaimed to amass in living organisms, especially toxic metals, such as $\mathrm{As}, \mathrm{Cd}$, and $\mathrm{Pb}$, health risk assessments are conducted on the basis of heavy metal concentration found in paddy plants and soils to evaluate the potential health risk [26]. The heavy metal taken up from plants may transfer into the food chain and adversely affect human health, depending on their carcinogenicity [26]. People are potentially exposed to toxic metals and metalloids from rice, especially those who take it as staple food for daily energy requirement. The tolerable daily intake (TDI) for $\mathrm{Cd}, \mathrm{Hg}$, and As, which are highly toxic to human exposure, are recommended to be $1.0 \mu \mathrm{g} / \mathrm{kg}$ body weight (bw)/day, $0.57 \mu \mathrm{g} / \mathrm{kg}(\mathrm{bw}) /$ day, and 2 to $7 \mu \mathrm{g} / \mathrm{kg}(\mathrm{bw}) /$ day, respectively [27].

Understanding the soil-metals uptake mechanisms in food crop is essential for devising the effective remediation process. In order to achieve this goal, this review initially describes the mechanism of heavy metal uptake in paddy plants and soils and their contributing factors with respect to bioaccumulation. Impressively, this review tries to provide an overview on the human risk assessment in relation to non-carcinogenic and carcinogenic risk. In this regard, it also covers information regarding in vitro digestion models that can be conducted to determine the bioaccessible form of heavy metals.

\section{Heavy Metal Contamination in Paddy Plants and Soils}

Table 1 shows the summary of heavy metal concentration in paddy plants and soil in selected areas of different countries. A study conducted by Singh et al. [28] at Ramgarh Lake, India, found that the $\mathrm{Zn}, \mathrm{Cr}, \mathrm{Cu}$, and $\mathrm{Pb}$ contents are higher in the cropped soils rice plants as compared to different parts of rice plants, except for $\mathrm{Cd}$ and As, which is due to their adsorptive nature in soil [29]. Meanwhile, the metals in rice plants are found to be mostly accumulated in the roots, rather than in other parts, such as stalk and grain sub-samples. Generally, As is found to be of the highest metal uptake by the roots in experimental sites, whereas, in the grains, the As concentration were less than in the roots and straw of paddy crops. Liu et al. [30] suggested that roots function as barrier for metal translocation by protecting stem and grain parts from metal contamination. Looi et al. [31] also have reported that concentration of As was found to be the highest $(4.62 \mathrm{mg} / \mathrm{kg})$ in 
roots due to the presence of iron plague on root surface that is highly associated with As accumulation, as shown in Table 1.

Meanwhile, at East Coast of India, specifically in East Coast Road (ECR), Tamil Nadu, Satpathy et al. [32] reported that $\mathrm{Zn}$ was of the highest and cadmium (Cd) was of the lowest concentrations of heavy metals in paddy soils. For different parts of paddy plants, the finding is almost similar to Singh et al. [28], where most of the metals accumulated more in the roots than in other parts, which are shoots and grains. The element $\mathrm{Zn}$ which is known as a micronutrient, is of the highest metal uptake in roots, followed by $\mathrm{Pb}, \mathrm{Cr}, \mathrm{Cu}$, and $\mathrm{Cd}$. Most metals in paddy plants, such as $\mathrm{Fe}, \mathrm{Mn}, \mathrm{Zn}$, and $\mathrm{Cu}$, were found extensively and they are micronutrients that were required in various enzyme activities and play significant roles in photosynthesis and growth of the plants [33,34]. The concentration of $\mathrm{Cd}$ in shoots was greater than roots and grain, since $\mathrm{Cd}$ was easily taken up by plants and transported to different parts, although there is no beneficial effects and it is nonessential for plants and animals [35]. Besides, this metal also reduced the photosynthesis and uptake of nutrient when the plants are exposed [36].

In China, paddy soils that were collected from three areas of Hunan Province during harvest season in 2013 were severely polluted with Cd with a total mean of $1.4 \mathrm{mg} / \mathrm{kg}$ [37], which are significantly higher as compared to the Chinese environmental quality standard $(0.3 \mathrm{mg} / \mathrm{kg})$ and the corresponding background values of Hunan $(0.098 \mathrm{mg} / \mathrm{kg})$. The variation in $\mathrm{Cd}$ concentration was associated with the geology area and resulting from human mining activities [37]. Similarly, other elements, such as As and Pb, showed a slightly higher concentration in comparison with standard and background values due to agriculture activities, including the application of various pesticides and fertilizers $[38,39]$. Moreover, studies that were conducted on the paddy soil from Nanxun and Suxian counties revealed that $\mathrm{Zn}$ and $\mathrm{Pb}$ concentration had the largest mean value, both exceeding $100 \mathrm{mg} / \mathrm{kg}[40,41]$.

The excessive usage of pesticide and herbicide could result in the accumulation of $\mathrm{Zn}$, $\mathrm{Pb}, \mathrm{As}$, and $\mathrm{Cu}$ in the topsoil of agricultural fields [42]. Hence, the long-term application of fertilizer and pesticides may influence the level of heavy metal in soils $[43,44]$. The element of As in rice grain from Gangneung, South Korea, and Zhejiang Province, China has accumulated by $0.13 \mathrm{mg} / \mathrm{kg}$ and $0.08 \mathrm{mg} / \mathrm{kg}$, respectively [45,46]. It was reported that As can be easily and largely accumulate by all cereal types due to its high bioavailability under reduced soil conditions [47]. Moreover, rice crop has great efficiency in assimilating As into grain as compared to other staple cereal crops [48]. Zeng et al. [37] reported that the concentration of As in brown rice may not only be affected from soil concentration, it but could also by other factors, such as physical-chemical properties of the growing soil, including the equilibrium $\mathrm{pH}$ that affect heavy metal sorption and desorption on soil components. According to Du et al. [49], most of the soils in Hunan are acidic and they may enhance the mobility of heavy metals from soil to rice.

In Malaysia, Khairiah et al. [50] and Looi et al. [31] studied the heavy metal accumulation of paddy cultivation in Kedah, whereas the study in Sabah was conducted by Yap et al. [51], Aziz et al. [52], and Payus et al. [53] in three different areas. Based on Table 1, the concentration of $\mathrm{Cd}$ in rice grain and other parts of paddy plants, such as leaf, stem, and roots by Khairiah et al. [50] was lower when compared to Yap et al. [51]. The authors reported that the application of pesticides and fertilizers in Langkawi did not influence the increase of $\mathrm{Cd}$ content in paddy plant. The level of $\mathrm{Cr}$ in paddy root, as reported by Payus et al. [53], was greater than shoot part. which includes main stem and plant above $10 \mathrm{~cm}$ from root postulated due to occurrence of redox reaction in plants that caused the movement of chromium from root to the shoot part. Moreover, chromium (III) can also react with carboxylic functional groups $(-\mathrm{COOH})$ in plants. This kind of reaction can distract the translocation of the metal elements from root to shoot and, thus, result in low $\mathrm{Cr}$ concentration in shoot parts [54]. Most of the metals $(\mathrm{Pb}, \mathrm{Cd}, \mathrm{Cr}$, and $\mathrm{Cu})$ concentrate in roots of paddy, except for $\mathrm{Zn}$, which is highly accumulated in the stems of paddy and soils. The accumulation of $\mathrm{Zn}$ in plants is due to the absorption of the metal by roots from the 
plants that are enclosed with soil [55]. The plants require the Zn element as an important nutrient in order to synthesize proteins, hormone growth, and reproductive processes of plants. Nonetheless, the excessive level of $\mathrm{Zn}$ in plants, which is more than $200 \mathrm{mg} / \mathrm{kg}$, will cause toxicity, resulting in stunted root growth and undersized leaves in plants [55].

Table 1. Summary of heavy metals concentration in paddy plants and soil in selected areas of different countries.

\begin{tabular}{|c|c|c|c|c|c|c|c|c|}
\hline \multirow{2}{*}{ Area of Study } & \multirow{2}{*}{ Sample(s) } & \multicolumn{6}{|c|}{ Mean Concentration of Heavy Metals (mg/kg) } & \multirow{2}{*}{ References } \\
\hline & & Cd & As & $\mathbf{P b}$ & $\mathrm{Cr}$ & $\mathrm{Cu}$ & $\mathrm{Zn}$ & \\
\hline \multirow{2}{*}{$\begin{array}{c}\text { Nanxun County, } \\
\text { China }\end{array}$} & Rice grain & 0.01 & - & - & - & 2.49 & 14.28 & \multirow{2}{*}{ Zhao et al. [40] } \\
\hline & Soil & 0.21 & - & 33.2 & - & 31.06 & 106.82 & \\
\hline \multirow{4}{*}{$\begin{array}{l}\text { Ramgarh Lake, } \\
\text { Gorakhpur, UP, } \\
\text { India }\end{array}$} & Roots & 6.16 & 22.77 & 7.09 & 2.93 & 2.09 & 2.24 & \multirow{4}{*}{ Singh et al. [28] } \\
\hline & Rice grain & 0.01 & 0.08 & 0.54 & 0.09 & - & - & \\
\hline & Rice straw & 0.64 & 0.87 & 1.88 & - & - & - & \\
\hline & Soil & 0.05 & 7 & 23 & 62.5 & 24 & 73 & \\
\hline \multirow{5}{*}{$\begin{array}{l}\text { Kompipinan, } \\
\text { Papar district, } \\
\text { Sabah, Malaysia }\end{array}$} & Roots & 0.38 & - & 7.7 & 5.46 & 4.94 & 16.08 & \multirow{5}{*}{ Payus et al. [53] } \\
\hline & Stem & 0.11 & - & 0.04 & 3.26 & 0.38 & 29.6 & \\
\hline & Leaf & 0.11 & - & 0.26 & 4.34 & 0.71 & 12.4 & \\
\hline & Grain & 0.13 & - & 2.06 & 4.12 & 0.74 & 12.75 & \\
\hline & Soil & 0.32 & - & 8.03 & 4.16 & 6.62 & 13.89 & \\
\hline \multirow{6}{*}{$\begin{array}{l}\text { Gangneung, } \\
\text { South of Korea }\end{array}$} & Rice & 0.01 & 0.13 & 0.01 & - & - & - & \multirow{6}{*}{ Choi et al. [45] } \\
\hline & Rice seed & 0.001 & 0.22 & 0.1 & - & - & - & \\
\hline & Rice straw & 0.04 & 0.81 & 0.03 & - & - & - & \\
\hline & Rice root & 0.05 & 2.07 & 5.29 & - & - & - & \\
\hline & Fertilizer & 0.01 & 1.22 & 5.61 & - & - & - & \\
\hline & Soil & 0.1 & 0.54 & 5.93 & - & - & - & \\
\hline \multirow{4}{*}{$\begin{array}{l}\text { Kubang Pasu, } \\
\text { Kedah, Malaysia }\end{array}$} & Soil & 0.2 & 0.6 & 3.72 & 2.3 & - & - & \multirow{4}{*}{ Looi et al. [31] } \\
\hline & Root & 0.29 & 4.62 & 1.35 & 0.57 & - & - & \\
\hline & Stem & 0.06 & 0.02 & 0.07 & 0 & - & - & \\
\hline & Grain & 0.01 & 0.06 & 0.21 & 0.04 & - & - & \\
\hline \multirow{2}{*}{$\begin{array}{c}\text { Hunan Province, } \\
\text { China }\end{array}$} & Soil & 1.4 & 16.8 & 51.4 & 27.2 & - & - & Zeng et al. [37] \\
\hline & Brown rice & 0.31 & 0.34 & 0.02 & 0.106 & - & - & \\
\hline & & \multicolumn{6}{|c|}{ Mean concentration of heavy metals ( $\mathrm{mg} / \mathrm{kg}$ ) } & \multirow{2}{*}{ References } \\
\hline Area of study & Sample(s) & Cd & As & $\mathbf{P b}$ & $\mathrm{Cr}$ & $\mathrm{Cu}$ & $\mathrm{Zn}$ & \\
\hline $\begin{array}{l}\text { Suxian County, } \\
\text { South China }\end{array}$ & Soil & 2.94 & 64.51 & 179.63 & - & 46.62 & - & Song et al. [41] \\
\hline \multirow{2}{*}{$\begin{array}{c}\text { Ranau Valley, } \\
\text { Sabah, Malaysia }\end{array}$} & Soil & 0.45 & 3.54 & - & 3360.56 & 154.83 & 229.98 & \multirow{2}{*}{ Aziz et al. [52] } \\
\hline & Rice grain & 0.54 & 0.05 & - & 1.61 & 2.61 & 37.48 & \\
\hline \multirow{6}{*}{$\begin{array}{c}\text { Kota Marudu, } \\
\text { Sabah, Malaysia }\end{array}$} & Rice & 0.18 & - & ND & 1.34 & 0.31 & 0.69 & \multirow{6}{*}{ Yap et al. [51] } \\
\hline & Husk & 0.18 & - & ND & 0.73 & 0.19 & 0.52 & \\
\hline & Leaf & 0.2 & - & ND & 1.02 & 1.24 & 1.21 & \\
\hline & Stem & 0.24 & - & $\mathrm{ND}$ & 0.71 & 1.53 & 0.68 & \\
\hline & Root & 0.19 & - & 1.57 & 1.86 & 9.25 & 2.31 & \\
\hline & Soil & 0.78 & - & ND & 2.08 & ND & 21.09 & \\
\hline
\end{tabular}


Table 1. Cont.

\begin{tabular}{|c|c|c|c|c|c|c|c|c|}
\hline \multirow{2}{*}{ Area of Study } & \multirow{2}{*}{ Sample(s) } & \multicolumn{6}{|c|}{ Mean Concentration of Heavy Metals (mg/kg) } & \multirow{2}{*}{ References } \\
\hline & & $\mathrm{Cd}$ & As & $\mathbf{P b}$ & $\mathrm{Cr}$ & $\mathrm{Cu}$ & Zn & \\
\hline $\begin{array}{c}\text { Zhejiang } \\
\text { Province, China }\end{array}$ & Rice & 0.04 & 0.08 & 0.06 & - & - & - & Huang et al. [46] \\
\hline \multirow{4}{*}{$\begin{array}{l}\text { East Coast Road } \\
\text { (ECR), India }\end{array}$} & Soil & $0.02-0.60$ & - & $\begin{array}{l}5.30- \\
19.80\end{array}$ & $1.30-7.80$ & $0.03-5.40$ & $3.80-33.8$ & \multirow{4}{*}{$\begin{array}{c}\text { Satpathy et al. } \\
\text { [32] }\end{array}$} \\
\hline & Shoot & $0.20-0.30$ & - & $0.30-1.20$ & $0.40-0.90$ & $0.04-0.30$ & $2.30-6.00$ & \\
\hline & Root & $0.11-0.20$ & - & $3.60-5.30$ & $0.60-1.70$ & $0.20-0.50$ & $\begin{array}{l}4.70- \\
16.90\end{array}$ & \\
\hline & Grain & $0.02-0.05$ & - & $0.01-1.00$ & $0.10-0.60$ & $0.10-0.30$ & $3.20-7.20$ & \\
\hline \multirow{5}{*}{$\begin{array}{c}\text { Langkawi, } \\
\text { Kedah, Malaysia }\end{array}$} & Rice & $0.02-0.04$ & - & $0.06-0.08$ & - & $0.04-0.08$ & $0.18-0.22$ & \multirow{5}{*}{$\begin{array}{l}\text { Khairiah et al. } \\
\text { [50] }\end{array}$} \\
\hline & Leaf & $0.01-0.02$ & - & $0.06-0.09$ & - & $0.20-0.52$ & $3.71-7.17$ & \\
\hline & Stem & $0.01-0.02$ & - & $0.04-0.08$ & - & $0.07-0.24$ & $0.78-1.08$ & \\
\hline & Root & 0.02 & - & $0.10-1.06$ & - & $0.08-0.34$ & $0.77-1.16$ & \\
\hline & Soils & $0.01-0.03$ & - & $0.28-0.51$ & - & $0.14-0.20$ & $0.23-0.47$ & \\
\hline
\end{tabular}

Note: -, Not included in analysis; ND, Not Detected.

\section{Mechanism of Heavy Metals Uptake in Plants}

Many researchers have investigated contaminant uptake and its mechanism by plants. It might be useful to regulate the contributing factors to enhance the mechanism of plant uptake. With reference to Usman et al. [56], the plants normally play its role both as "accumulators" and "excluders". Accumulators sustain even with concentrating contaminants in their aerial parts. The plants biotransform or biodegrade the contaminants into inactive forms in their tissues. The excluders, in principle, limit the uptake of contaminant into their biomass.

Plants have developed very specific and highly efficient mechanisms to attain crucial micronutrients from the environment, albeit when existing at low ppm and ppb levels. The plant roots, which are assisted by plant-producing chelating agents and plant-inducing $\mathrm{pH}$ changes and redox reactions, can dissolve and absorb micronutrients from down levels in the soil, even from partly not soluble sediments. Plants have also changed very explicit mechanisms to translocate and store micronutrients in their parts. The same mechanisms are also embraced in the uptake, translocation, and storage of heavy metals, where the nature of the chemical property's mimics those of essential elements. Therefore, mechanisms of micronutrient uptake are of great attention to phytoremediation [57].

The array of known transport mechanisms set in the plant cell plasma membrane included in ion uptake and translocation involve (i) co- and anti-transporters (proteins that utilize the electrochemical gradients that are produced by ATPases to initiate the active uptake of ions), (ii) proton pumps (ATPases that occupy energy and produce electrochemical gradients), and (iii) channels (proteins that ease the transport of ions into the cell). A range of ions is likely will be taken up by each transport mechanism. The ionic species interaction during several heavy metal contaminants uptake is the primary problem in the mechanism of uptake. Following roots uptake, the translocation of contaminants into shoots is required, since the harvest of biomass from root is generally not achievable. There were lack of information concerning which forms of metal ions are translocated from the roots to the shoots [58].

Heavy metals uptake mechanisms by plants are expected to be strictly controlled. Plants, in general, do not accumulate trace elements over their metabolic needs. Such settings are trivial in the range of 10 to $15 \mathrm{ppm}$ of most trace elements suitable for most needs [59]. The exemptions are plants that are classified as "hyperaccumulator", which can absorb toxic metal ions at a concentration in the thousands of ppm. In addition, other mat- 
ter is the form of which toxic metal ions are accumulated in the plants, specifically in hyperaccumulator, and how these plants are resistant to metal toxicity. In principle, manifold mechanisms are involved; including the storage in the plant's vacuole seems to be a major one [60].

Evapotranspiration is a term used to explain the process of water evaporating from plant leaves into plant roots. The water serves as a pump to disseminate nutrients absorbed to the plant roots and shoots. The original soil was leaved undisturbed in order to remove contamination from roots to shoots. The plants that execute a shoot-to-a metalconcentration ratio that is greater than one are called "hyperaccumulators", and these plants are normally used in phytoextraction strategies. Otherwise, the plants with shootto-root ratio less than one are categorized as non-accumulating plants. Theoretically, toxic environment should be flourished with hyperaccumulators, where it requires less maintenance and generates high biomass [61].

Heavy metals, like $\mathrm{Cd}, \mathrm{Zn}, \mathrm{Co}, \mathrm{Mn}, \mathrm{Ni}$, and $\mathrm{Pb}$, can be accumulated by metal accumulating plant species concentrated up to 100 or 1000 times higher than the excluder (non-accumulator) plants. Typically, microorganisms living in the rhizosphere, like bacteria and fungi, may promote mobilizing metal ions and increase the bioavailable fraction [62,63].

Figure 1 showed the proposed mechanism of As uptake in paddy plants by Zhao et al. [64]. The As speciation in rice grain is dominated by dimethylarsinic acid ( $\mathrm{DMA}^{\mathrm{V}}$ ) and inorganic As (iAs), which are majorly composed of arsenite, As (III). The total iAs is generally reported by the sum of two species through the conversion between As (III) and arsenate, As (V), which may occur during some extraction procedures [65]. In the biotransformation process, these iAs are converted to methylated arsenicals by enzymes, which are the biomarker of chronic arsenic exposure and the end metabolites [65]. Verbruggen et al. [66] reported that the phosphate transporters in As translocation manage the influx of arsenate, whereas the arsenite is taken up via aquaporin nodulin 26-like intrinsic proteins. In the xylem sap of plants, inorganic As (V) and As (III) are the major arsenicals found [67]. A very small proportion of As is translocated to shoot tissue (leaf), where similar reduction and sequestration mechanisms exist and, via the phloem, some of the total As content ceases in the vacuoles and other parts of edible tissue, such as rice grain [67]. Different rice varieties and rice genotypes have shown significant differences in accumulating As at its higher concentration [68]. This might be partly due to the surface characteristics of rhizosphere, which also play an important role in iron plague formation of reddish-brown coating on the root surface [68].

Besides As, the irrigation water in paddy field often also causes loads of Cd in soil. It accumulates in grains following four major transport processes, namely (1) the uptake of Cd by root, (2) root-to-shoot translocation by xylem flow, (3) redirection of nodes, and (4) remobilization from leaves [69]. When the element $\mathrm{Cd}$ binds to cysteine-rich protein, such as metallothionein, their concentrations are increased to 3,000-fold [65]. Phytochelatins (PCS) has been classified as class III metallothioneins and Cd is known as the strongest inducer for their biosynthesis [70]. The Cd element is able to form complexes with PCS and is transported to vacuoles [71]. PCS-metal complexes possibly form a more complex aggregation in vacuole by isolating toxic metals from various metal sensitive enzymes in plant cell cytoplasm [71]. 


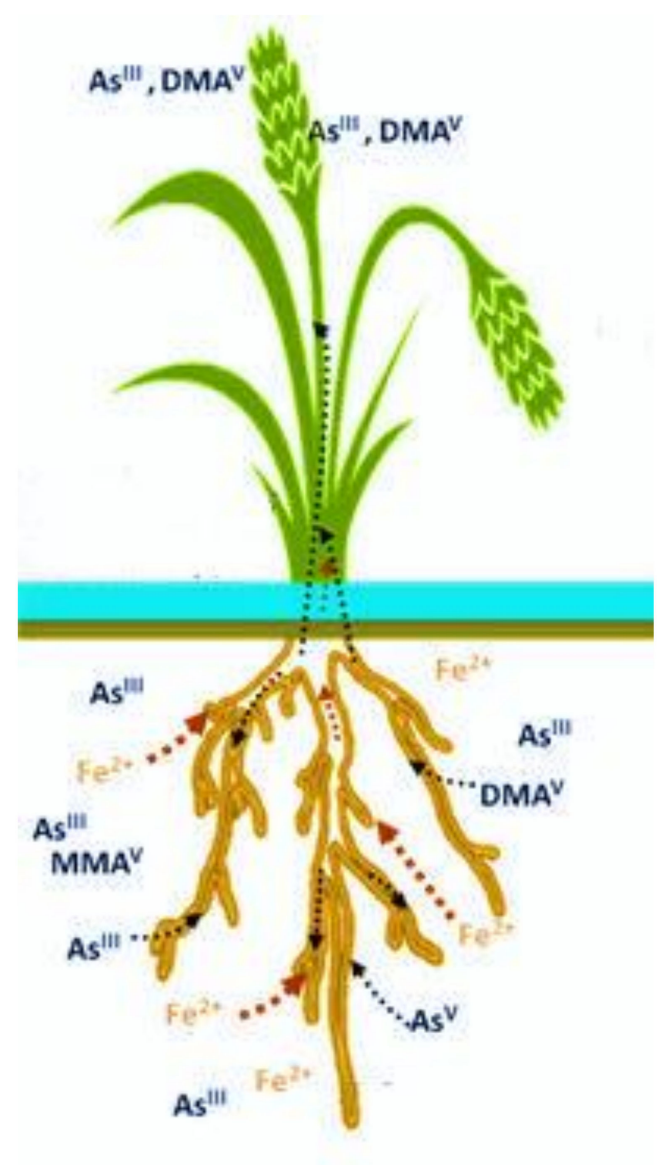

Figure 1. Uptake mechanism of arsenic in paddy plants. Adapted from Zhao et al. [55]. Copyright permission granted by Copyright Clearance Center.

\subsection{Factors Affecting the Uptake Mechanisms}

There are several factors that can affect the uptake mechanism of heavy metals, as shown in Figure 2. By having knowledge about these factors, the uptake performance by plant can be greatly improved.

\subsubsection{The Plant Species}

Plant species or varieties play important roles in the phytoremediation process, which includes phytofiltration, phytoextraction, phytostabilization, phytovolatilation, phytodegradation, and rhizodegradation [72,73]. The uptake of a compound is affected by plant species characteristics [73]. The success of the phytoremediation depends upon the identification of suitable plant species that hyperaccumulate heavy metals and produce large amounts of biomass while using established crop production and management practices [74]. Various plants have different responses toward various heavy metals exposure. Some plants are sensitive, whereas others have a high tolerance to several heavy metals. As a result of plant-metal interaction, some plants accumulate heavy metals from soil and, thus, their growth and development declines. Nevertheless, some plants have a high tolerance and they maintain their growth and development below heavy metals stress [73].

\subsubsection{The Properties of Medium}

Remediation enhancement via $\mathrm{pH}$ adjustment, the addition of chelators, and fertilizers employed in agronomical practices may affect metals uptake [75]. As such, to reduce the amount of lead absorbed by plants, the $\mathrm{pH}$ of the soils is adjusted to a level of 6.5 to 7.0. This is due to lead absorption being affected by the $\mathrm{pH}$, organic matter, and phosphorus content of the soil [76]. 


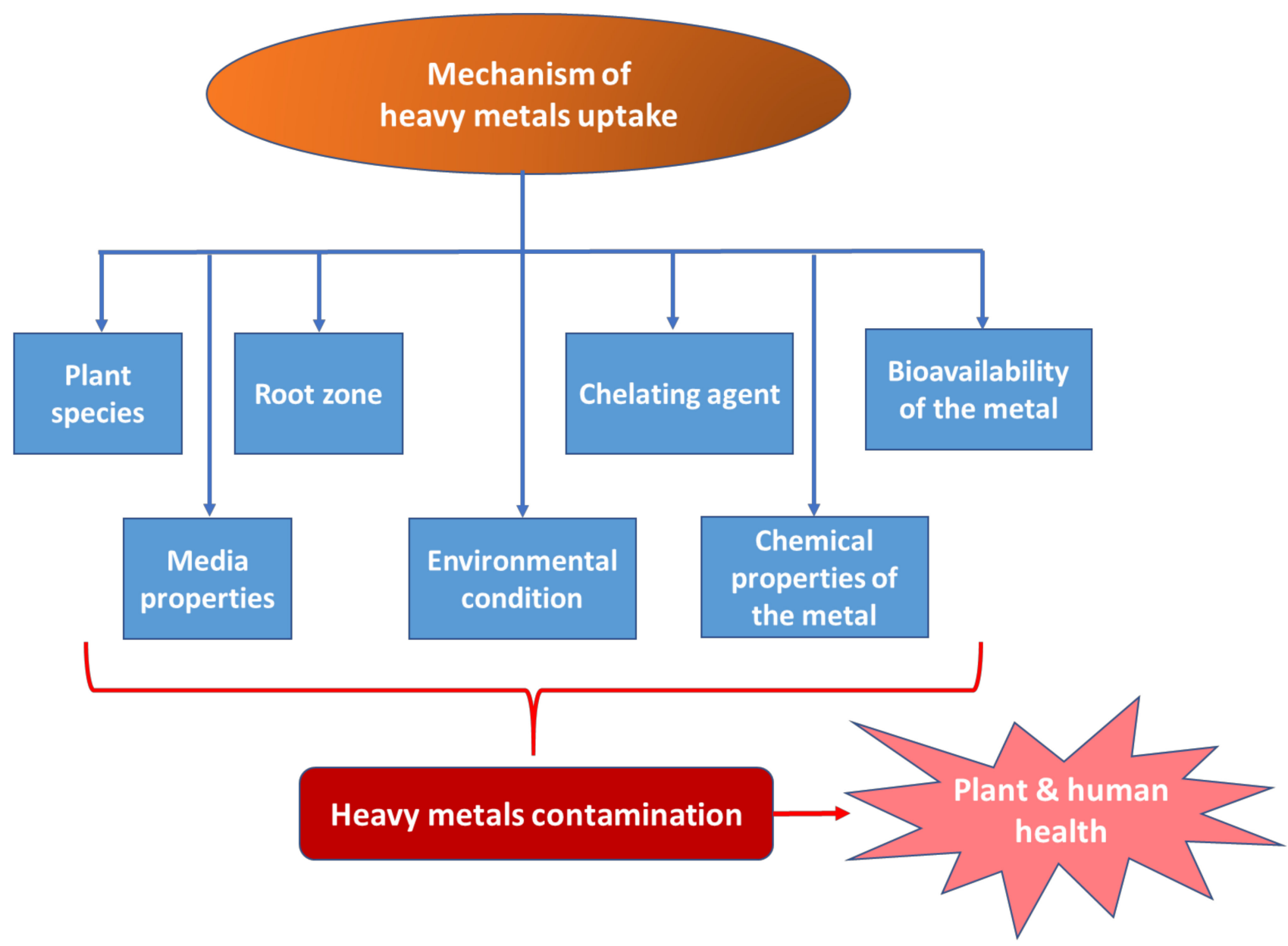

Figure 2. Factors which are affecting the uptake mechanisms of heavy metals.

\subsubsection{The Root Zone}

The root zone is of special interest of the plant tissues in phytoremediation. Th root is able to absorb, store, or metabolize contaminants inside the plant tissue. Another phytoremediation mechanism is the degradation of contaminants in the soil by plant enzymes and rhizospheric microorganisms that exudes from the plant's roots via phytodegradation and rhizodegradation, respectively [73]. As a result of morphological adaptation to drought stress, the root diameter of a plant is increased, and root elongation is reduced as a response to less permeability of the dried soil [77].

\subsubsection{Vegetative Uptake}

Environmental conditions will affect the vegetative uptake [78], where the temperature affects the growth substances and, subsequently, root length. There are differences in terms of the structure between the root under field conditions and greenhouse conditions [79]. Contaminant-specific hyperaccumulator will determine the success of phytoremediation, specifically the phytoextraction [80]. The key to proving the applicability of phytoremediation is to understand the mass balance analyses and the metabolic fate of pollutants in plants [81]. The bioavailability of the metal in the water phase will determine the metal uptake by plants. This is supported by the retention time and interaction of the metal with other elements and substances in the water. Moreover, the metal-soil bound, $\mathrm{pH}$, redox potential, and organic matter content are other factors that affect the tendency of the metal to exist in ionic and plant-available form. The ability of plants to lower the $\mathrm{pH}$ and oxygenate the sediment will affect the soil condition and metal content [82]. Chelating 
agents and micronutrients as biodegradable physicochemical factors are also added to increase the bioavailability of the heavy metals [83].

\subsubsection{The Chelating Agent}

Increasing the bioavailability of heavy metals through the addition of biodegradable physicochemical factors, such as chelating agents and micronutrients, can influence the uptake of heavy metals by the energy crops. Other than that, microbial community in and around the plant will also stimulate the heavy metal uptake capacity. Consequently, the remediation periods will become shorter and less expensive. The use of synthetic chelating agent in heavy metal contaminated soil could promote the leaching of the contaminants into the soil. Therefore, the proper usage of the agent has to be taken in consideration [84]. For example, the use of a chelating agent may be required in alkaline soils since the bioavailability of heavy metals in soils decreases above $\mathrm{pH}$ 5.5-6. The metal translocation in plant tissue as well as the overall phytoextraction performance has been improved when exposing the plants to EDTA for longer period (two weeks) [85]. The bioavailability of metals is affected by citrate and oxalate that are exuded by plant roots. The enhancement of phytoextraction of soil-polluting heavy metals is aided by chelate-assisted phytoremediation chelating agents, such as NTA and EDTA. The presence of a ligand affects the bio uptake of heavy metals through the formation of metal-ligand complexes and it changes the potential to leach metals below the root zone [86].

\subsection{Bioaccumulation Factor (BAF)}

The soil-to-rice transfer factor or bioaccumulation factor (BAF) is an index for evaluating the potential of a metal transfer from soil to plant [87]. BAF is calculated for each rice sample by the ratio of the element concentration in the grain to that in the corresponding soil to quantify the bioaccumulation effect of rice towards the heavy metal uptake from the soils $[12,88,89]$ (Equation (1)). The BAF is measured as:

$$
\mathrm{BAF}=\mathrm{Cr} / \mathrm{Cs}
$$

where $\mathrm{Cr}$ and $\mathrm{Cs}$ represent the heavy metal concentrations in rice grain and soils, respectively, based on the basis of dry weight $(w / w)$ in $\mathrm{mg} / \mathrm{kg}$. If the BAF is $\leq 1$, then the value denotes that the plant is able to absorb the heavy metals, but do not accumulate, whereas BAF $>1$ means that the heavy metals accumulate in plants [28,32]. According to Ma et al. [90] and Cluis [91], BAF is further classified as hyperaccumulators and excluder to the samples that accumulate metals $>1 \mathrm{mg} \mathrm{kg}^{-1}$, and $<1$, respectively. The toxic effect of heavy metals from excluder plant is restricted to the roots, which is then detoxified, and the aerial parts of plants remain more or less unaffected. Meanwhile, the hyperaccumulator plants are able to accumulate without phytotoxicity symptoms in their aboveground parts, even if exposed to high concentration of heavy metals [92,93].

Table 2 summarizes BAF values in paddy plants from different areas by several studies. The toxic metals, such as mercury $(\mathrm{Hg})$ and cadmium $(\mathrm{Cd})$, were found to be higher than other studied metals in BAF values by Singh et al. [28] and Satpathy et al. [32], respectively. However, the BAF values for both toxic metals were less than one, which indicates that the plants only absorb the heavy metals and are not metal accumulators. Hence, the local inhabitants of respective areas have low exposure to heavy metal, since the soil-to-plant transfer is one of the key components of human exposure to metals via food chain [94]. From Table 2, the BAF values for Mn (1.88) from Neeratanaphan et al. [95] and all metals $(\mathrm{Zn}, \mathrm{Cd}, \mathrm{Cr}, \mathrm{Pb}$, and $\mathrm{Cu}$ ) from Payus et al. [53] were more than 1, which indicated that Oryza sativa is a hyper accumulator plant with high potential to absorb metals from the soil [96]. The accumulation, uptake, and phytotoxicity may also vary, depending on cultivars used. Previously, Xie and Huang [97] discovered that there were significant differences for the uptake and accumulation of As in different parts of plants among the 11 rice cultivars planted in As-polluted paddy fields. However, there were no significant differences found by $\mathrm{Xie}$ at al. [98] for $\mathrm{BAF}$ of $\mathrm{Pb}, \mathrm{Cd}, \mathrm{Cr}, \mathrm{As}$, and $\mathrm{Cu}$ among the conventional rice, two-line 
hybrid rice, and three-line hybrid rice, which indicate that different rice varieties from the same soil background have no relation to the bioaccumulation ability of heavy metals for rice.

Table 2. Summary of the bioaccumulation factor (BAF) values in paddy plants from different areas.

\begin{tabular}{|c|c|c|c|c|c|c|c|c|c|}
\hline \multirow{2}{*}{ Area of Study } & \multicolumn{8}{|c|}{ Bioaccumulation Factor (BAF) Values } & \multirow{2}{*}{ References } \\
\hline & As & Cd & $\mathrm{Pb}$ & $\mathrm{Cr}$ & $\mathrm{Cu}$ & $\mathrm{Zn}$ & Mn & $\mathrm{Hg}$ & \\
\hline $\begin{array}{l}\text { Dabaoshan mine, } \\
\text { South China }\end{array}$ & - & 0.20 & 0.005 & - & 0.013 & - & - & - & $\begin{array}{c}\text { Zhuang et al. } \\
\text { [94] }\end{array}$ \\
\hline Jiangsu Province, China & 0.025 & 0.178 & 0.005 & 0.006 & 0.196 & 0.258 & - & 0.047 & Hang et al. [12] \\
\hline $\begin{array}{c}\text { Ramgarh Lake, } \\
\text { India (Control site) }\end{array}$ & 0.014 & 0.016 & 0.03 & 0.002 & 0.002 & 0.007 & 0.038 & 0.272 & \multirow{2}{*}{ Singh et al. [28] } \\
\hline $\begin{array}{c}\text { Ramgarh Lake, } \\
\text { India (Experimental site) }\end{array}$ & 0.016 & 0.017 & 0.028 & 0.001 & 0.002 & 0.008 & 0.032 & 0.308 & \\
\hline $\begin{array}{l}\text { East Coast Road (ECR), } \\
\text { India }\end{array}$ & - & $0.05-0.20$ & $0.001-0.60$ & $0.04-0.07$ & $0.04-0.10$ & $0.20-0.50$ & $0.10-0.20$ & - & $\begin{array}{c}\text { Satpathy et al. } \\
{[32]}\end{array}$ \\
\hline $\begin{array}{l}\text { Kompipinan Papar } \\
\text { district, Sabah }\end{array}$ & - & 4.12 & 1.28 & 4.00 & 1.03 & 5.16 & - & - & Payus et al. [53] \\
\hline Ranau Valley, Sabah & $0.24-0.89$ & - & - & $0.00-0.01$ & $0.00-0.03$ & $0.07-0.10$ & $0.01-0.02$ & - & Aziz et al. [52] \\
\hline Isfahan Province, Iran & - & $0.50-1.80$ & $0.15-0.20$ & - & - & $0.20-0.50$ & - & - & $\begin{array}{l}\text { Rahimi et al. } \\
\text { [99] }\end{array}$ \\
\hline $\begin{array}{l}\text { Kalasin Province, } \\
\text { Thailand }\end{array}$ & - & - & 0.23 & 0.10 & - & - & 1.88 & - & $\begin{array}{c}\text { Neeratanaphan } \\
\text { et al. [95] }\end{array}$ \\
\hline
\end{tabular}

Note: -, Not included in analysis.

\subsection{Translocation Factor (TF)}

The translocation factor (TF) is known as an indicator of heavy metal accumulation in plants or mobility of heavy metals in the soil and it also quantifies the differences in the bioavailability of metal to plant [100]. According to Barman et al. [101] and Gupta et al. [102], the TF or mobilization ratio was calculated to evaluate relative translocation of metals from soil to other parts, such as root, shoot, or grain, of the plant species, as follows (Equation (2)):

$$
\mathrm{TF}=\mathrm{Cs} / \mathrm{Cr}
$$

where Cs represents heavy metal concentration in plants' shoot and Cr represents heavy metal concentration in plants' soil or root [28]. The value of TF greater than 1 showed that the paddy plant is able to hyperaccumulate from roots to shoots, according to Rezvani and Zaefarian [103]. By evaluating TF, the bioavailability of heavy metals in investigated soils could be revealed. The higher the TF values are, the more mobile or available the metals are [104-106].

Table 3 summarizes TF values in paddy parts from different areas by various studies. The soil-to-root translocation in rice plant by Singh et al. [28] and Rahimi et al. [99] found that the $\mathrm{Cd}$ value is more than 1 , which indicates that rice root accumulated high quantities of $\mathrm{Cd}^{2+}$ when grown in polluted areas [107]. Because $\mathrm{Cd}^{2+}$ was substantiated to be more bioavailable than other heavy metals, hence, it resulted in higher biological absorption coefficient for $\mathrm{Cd}[28,108]$. There are certain species of plants that are capable of removing heavy metals from the soil and ground water through absorption and accumulation by roots, or precipitation within root zone [109]. Other than that, the application of genetic engineering on plants, such as transgenic rice, may significantly enhance plant abilities to uptake, translocate, and transform heavy metals, including limiting their toxicity [110]. The genetic modification in rice by enhancing drought tolerance can also potentially affect non-target organisms or nutrient mobilization, as discovered by Jeong et al. [111], due to overexpressing the OsNAC10 gene in roots that cause pleiotropic effects on other genes that play a role in nutrient mobilization. Thus, this modification might enhance the uptake 
of the metals, resulting in elevated metal concentration in the aboveground plant parts, which can affect essential nutrients and causes oxidative stress.

Table 3. Summary of the translocation factor (TF) values in paddy plants from different areas.

\begin{tabular}{|c|c|c|c|c|c|c|c|c|c|c|}
\hline \multirow{2}{*}{ Area of Study } & \multirow{2}{*}{ Paddy Parts } & \multicolumn{8}{|c|}{ Translocation Factor (TF) Values } & \multirow{2}{*}{ References } \\
\hline & & As & Cd & $\mathrm{Pb}$ & $\mathrm{Cr}$ & $\mathrm{Cu}$ & Zn & Mn & $\mathrm{Hg}$ & \\
\hline \multirow{3}{*}{$\begin{array}{c}\text { Ramgarh Lake, } \\
\text { India (Control } \\
\text { site) }\end{array}$} & Soil to root & 4.19 & 11.34 & 0.39 & 0.04 & 0.07 & 0.02 & 0.16 & 0.96 & \multirow{6}{*}{$\begin{array}{l}\text { Singh et al. } \\
\text { [28] }\end{array}$} \\
\hline & Root to shoot & 0.04 & 0.08 & 0.22 & 0.33 & 0.07 & 0.41 & 0.43 & 0.71 & \\
\hline & Shoot to grain & 0.06 & 0.01 & 0.33 & 0.112 & 0.38 & 0.55 & 0.116 & 0.95 & \\
\hline \multirow{3}{*}{$\begin{array}{l}\text { Ramgarh Lake, In- } \\
\text { dia (Experimental } \\
\text { site) }\end{array}$} & Soil to root & 4.20 & 7.19 & 0.38 & 0.05 & 0.09 & 0.03 & 0.18 & 1.28 & \\
\hline & Root to shoot & 0.03 & 0.10 & 0.26 & 0.27 & 0.08 & 0.34 & 1.03 & 0.33 & \\
\hline & Shoot to grain & 0.09 & 0.02 & 0.28 & 0.10 & 0.29 & 0.75 & 0.54 & 0.71 & \\
\hline \multirow{3}{*}{$\begin{array}{l}\text { East Coast Road } \\
\text { (ECR), India }\end{array}$} & Soil to root & - & $0.30-0.60$ & $0.20-0.40$ & $0.20-0.30$ & $0.09-0.20$ & $0.40-0.90$ & $0.30-0.70$ & - & \multirow{3}{*}{$\begin{array}{c}\text { Satpathy et al. } \\
{[32]}\end{array}$} \\
\hline & Root to shoot & - & $1.30-2.40$ & $0.07-0.30$ & $0.50-0.80$ & $0.20-0.60$ & $0.20-0.50$ & $1.30-2.30$ & - & \\
\hline & Shoot to grain & - & $0.09-0.20$ & $0.04-0.80$ & $0.30-0.70$ & $1.10-2.50$ & $1.00-1.50$ & $0.20-0.30$ & - & \\
\hline $\begin{array}{c}\text { Ranau Valley, } \\
\text { Sabah, Malaysia }\end{array}$ & $\begin{array}{l}\text { Roots to } \\
\text { shoots }\end{array}$ & - & - & - & $0.03-0.06$ & $0.04-0.34$ & $2.01-2.48$ & $0.58-1.28$ & - & Aziz et al. [52] \\
\hline $\begin{array}{l}\text { Kompipinan } \\
\text { Papar district, } \\
\text { Sabah }\end{array}$ & $\begin{array}{l}\text { Roots to } \\
\text { shoots }\end{array}$ & - & 0.94 & 0.29 & 1.97 & 0.37 & 3.43 & - & - & $\begin{array}{l}\text { Payus et al. } \\
\text { [53] }\end{array}$ \\
\hline & Paddrunorts & \multicolumn{8}{|c|}{ Translocation Factor (TF) Values } & \multirow{2}{*}{ References } \\
\hline Area of Study & Paday parts & As & $\mathrm{Cd}$ & $\mathbf{P b}$ & $\mathrm{Cr}$ & $\mathrm{Cu}$ & Zn & Mn & $\mathrm{Hg}$ & \\
\hline \multirow{3}{*}{$\begin{array}{c}\text { Isfahan Province, } \\
\text { Iran }\end{array}$} & Soil to root & - & 1.52 & 0.486 & - & - & 0.389 & - & - & \multirow{3}{*}{$\begin{array}{l}\text { Rahimi et al. } \\
\text { [99] }\end{array}$} \\
\hline & Root to shoot & - & 0.688 & 0.656 & - & - & 0.732 & - & - & \\
\hline & Shoot to grain & - & 0.854 & 0.456 & - & - & 1.228 & - & - & \\
\hline \multirow{4}{*}{$\begin{array}{c}\text { Kalasin Province, } \\
\text { Thailand }\end{array}$} & Soil to root & - & - & 2.10 & 0.28 & - & 2.76 & - & - & \multirow{4}{*}{$\begin{array}{l}\text { Neeratanaphan } \\
\text { et al. [95] }\end{array}$} \\
\hline & Root to stem & - & - & 0.11 & 0.49 & - & 3.80 & - & - & \\
\hline & Stem to leaf & - & - & 3.23 & 1.40 & - & 1.90 & - & - & \\
\hline & Stem to grain & - & - & 1.67 & 1.14 & - & 0.22 & - & - & \\
\hline
\end{tabular}

Note: -, Not included in study.

\subsection{Enrichment Factor (EF)}

There is a limited study on the enrichment factor (EF) specifically for paddy plants and soil. EF was calculated in order to derive the degree of soil contamination and heavy metal accumulations in soil and in plants growing on contaminated site with respect to soil and plants growing on uncontaminated soil [112]. EF was calculated by the following equation (Equation (3)):

$$
\mathrm{EF}=\frac{\text { Concentration of metals in soil or plant parts at contaminated site }}{\text { Concentration of metals in soil or plant parts at uncontaminated site }}
$$

Satpathy et al. [32] found that all metals $(\mathrm{Cu}, \mathrm{Cd}, \mathrm{Zn}, \mathrm{Cr}, \mathrm{Mn}$, and $\mathrm{Pb})$ showed EF values that were greater than 1 , which indicates that the samples have relatively high potential to uptake metals from the soil [96]. In addition, the high availability and metal distribution in contaminated soils eventually cause metal accumulation in plant species grown in soil to increase [102,112]. Similarly, the EF values of eight metals $(\mathrm{Cr}, \mathrm{Cd}, \mathrm{Mn}, \mathrm{Pb}$, $\mathrm{As}, \mathrm{Zn}, \mathrm{Hg}$, and $\mathrm{Cu}$ ) in experimental soil, root, stem, and grain parts of paddy were greater than 1 [28]. Barman and Bhargava [113] reported that the EF value for edible parts, such as rice grain, is an important criterion for the selection of suitable crop species, which can be selected for cultivation in a field having an elevated level of metal contamination or receiving industrial effluent. 


\section{Human Diseases Associated with Heavy Metal Contamination in Rice}

Rice is a major crop globally and it is especially important in Asia $[114,115]$. Therefore, the information on rice consumption with toxic metal contamination and its health-related issue is of paramount importance. $\mathrm{Cd}, \mathrm{As}$, and $\mathrm{Pb}$ are among the major contaminant in rice in Asia, where they have been ranked as the most hazardous substances according to the criteria of frequency of occurrence in the environment, toxicity, and potential exposure to humans [116]. The increased risks of all-cancer mortality were reported due to long-term environmental exposure to Cd [117].

Studies that were conducted at a few locations in (a) Japan [118-120], (b) China [49], and (c) Thailand [121] similarly found the relationship between human $\mathrm{Cd}$ disease and the survival of rice farmers. Cadmium exposure was found to be related to the consumption of rice and presented a high risk to local farmers in Japan particularly the female farmers over 70 years of age had decreased function of renal tubular [119]. Locally produced rice in Japan was found to be contaminated with $\mathrm{Cd}$ and those people who had $\mathrm{Cd}$ poisoning from rice consumption suffered spinal and leg pain with other complications, including anaemia, coughing, and kidney failure, which primarily caused death [118]. This phenomenon is also known as the 'itai-itai' disease, which generally related to environmental pollution due to local mining activities in Japan. The heavy metal contamination and its accumulation in China has also become a serious and major environmental problem because of the continuous industrialization and urbanization [122,123]. The Hunan Province, for instance, which provides the main area for rice production, had a food safety issue in regards to the discovery of "Cd rice" [49], which resulted in a high incidence of malignant tumors among the local population $[117,124]$. Besides Japan and China, rice grains grown in Thailand, specifically at Mae Sot district of Tak Province, have elevated levels of Cd resulting in higher amounts of urinary Cd as compared to those living in other districts [121]. In 2010, Swaddiwudhipong and colleagues [125] have reported a greater excretion rate of urinary total protein, which reflects that $\mathrm{Cd}$ exposure might cause severe tubular damage and/or glomerular permeability to larger proteins. Therefore, cadmium-exposed persons should be screened for other medical conditions, such as diabetes and urinary stones, found to be related to proteinuria that lead to neuropathy.

Rice, together with other food and drinking water, may be a source of considerable combined exposure to inorganic arsenic. Inorganic arsenic, which is more toxic, is known to cause several diseases and cancers of different parts of the body, including the skin, cardiovascular system, and reproductive systems [126], and even diabetes through epigenetic mechanisms, as reported by several studies in South Asia [63]. Studies by Jayasumana et al. [127] revealed that the usage of phosphate fertilizer is a main source of As in areas that are affected with chronic kidney disease in Sri Lanka.

Moreover, among the hazardous heavy metals, $\mathrm{Pb}$ has been listed as "the chemical of great concern" by the new European REACH regulations, and it was known as the second most harmful pollutant following arsenic [128]. High levels of $\mathrm{Pb}$ in rice grain employed quality issues and adverse health implications to human liver, endocrine, and reproductive system [129].

\section{Health Risk Assessment (HRA) of Heavy Metals in Rice}

Health risk assessments (HRA) are generally focused on target populations by evaluating their potential health effects when exposed to certain toxic elements. HRA includes non-carcinogenic and carcinogenic risk assessments through three exposure pathways, which are ingestion, dermal contact, and inhalation, which have been recognized as important tools for identifying health risks in human activities and providing risk evidence for decision makers [130].

Indeed, rice consumption was considered to be the major pathway of human exposure to heavy metals [46]. The HRA that was conducted by Man et al. [131], Zota et al. [132], and Qu et al. [133] found that children are highly susceptible to heavy metal pollution as compared to adults due to their physiological and behavioral characteristics. The toxicity of metals in terms of toxicological effects may vary in each person. One way to predict 
their bioaccumulation and transformation is to develop a mathematical model for HRA when associated with heavy metal contamination, especially in soil [134].

There are various mathematical models for risk assessments, such as health risk index (HRI), target cancer risk (TCR), hazard index (HI), and target hazard quotient (THQ), which have been used to assess the carcinogenicity of the particular heavy metals present, especially in food and drinks. Table 4 tabulates the mathematical models for risk assessment on heavy metal exposure on rice consumption. Uncertainties might occur when conducting risk assessments from natural variability in an individual's response, variability in toxicants concentration, in measurement or parameters estimation, a lack of precise knowledge, and data scarcity $[135,136]$. Therefore, deterministic or stochastic approaches can be used as health risk assessment models. Monte Carlo Simulation (MCS) is an example of a stochastic approach, and it has been widely used in risk assessment. Djahed et al. [137] used MCS for both non-carcinogenic and carcinogenic risk assessments on rice consumption in Iran to specify the uncertainty by analyzing and controlling the existing uncertainty in the input parameters.

\subsection{Exposure Estimates}

Chronic daily intake (CDI) can be used to evaluate heavy metal exposure from soil through inhalation, dermal contact, and ingestion [122,138], whereas average daily dose (ADD) or estimated daily intake (EDI) can be measured for exposure from rice grain.

\subsubsection{Chronic Daily Intake (CDI)}

Heavy metals potentially accumulate in the human body through the food chain and, thus, constitute serious health threats [139]. There are three pathways that are involved in the estimation of the direct exposure to heavy metal via soil, which are: (i) the inhalation of particulates emitted from the soil, (ii) dermal contact with the soil, and (iii) incidental ingestion of the soil [122]. The CDI of these three exposure pathways can be defined employing U.S Environment Protection Agency (USEPA) methodology [140]. The exposure pathways can be measured using the following equation:

$$
\begin{gathered}
\mathrm{CDI}_{\text {Inhalation }}=\frac{\mathrm{PM}_{10} \times \mathrm{M}_{\mathrm{PM}} \times \mathrm{ET} \times \mathrm{IR}_{\text {air }} \times \mathrm{EF} \times \mathrm{ED}}{\mathrm{BW} \times \mathrm{AT} \times \mathrm{PEF}} \\
\mathrm{CDI}_{\text {Dermal }}=\frac{\mathrm{C}_{\text {soil }} \times \mathrm{SA} \times \mathrm{PE} \times \mathrm{AF} \times \mathrm{ABS} \times \mathrm{ED}}{\mathrm{BW} \times \mathrm{AT} \times 10^{6}} \\
\mathrm{CDI}_{\text {Ingestion }}=\frac{\mathrm{C}_{\text {soil }} \times \mathrm{IR}_{\text {air }} \times \mathrm{EF} \times \mathrm{ED}}{\mathrm{BW} \times \mathrm{AT} \times 10^{6}}
\end{gathered}
$$

where $\mathrm{PM}_{10}$ is the ambient particulate matter in the area of study $\left(\mathrm{mg} / \mathrm{m}^{3}\right) ; \mathrm{M}_{\mathrm{PM}}$ is the heavy metal concentration of airborne particulate matter, which is assumed to be equal to $\mathrm{C}_{\text {soil }}$, where dust is derived from the soils [141]; ET is the exposure time (hours/day); $\mathrm{IR}_{\text {air }}$ represents the inhalation rate of air $\left(\mathrm{m}^{3} /\right.$ day); $\mathrm{EF}$ is the exposure frequency (days/year); $\mathrm{ED}$ is the exposure duration (year); $\mathrm{C}_{\text {soil }}$ is the concentration of heavy metals in soil (mg/kg); $\mathrm{SA}$ is the skin surface area for soil contact $\left(\mathrm{cm}^{2} /\right.$ day); $\mathrm{FE}$ is the fraction of dermal exposure ratio to the soil; AF is the soil adherence factor $(\mathrm{mg} / \mathrm{cm})$; ABS is the fraction of applied dose absorbed across the skin; and, $10^{6}$ is the conversion factor, from $\mathrm{kg}$ to $\mathrm{mg}$.

Based on the findings from Liang et al. [138], soil ingestion was the main contributor in all of the soil exposure pathways, whereby the soil pathways are reduced in the order of ingestion > dermal absorption > inhalation. Similarly, Hu et al. [122] and Xiao et al. [142] also found the same trend of CDI values for ingestion, dermal absorption, and inhalation. Therefore, soil ingestion was the most significant contributor to the total health risk of inhabitants. 


\subsubsection{Average Daily Dose (ADD) and Estimated Daily Intake (EDI)}

$\mathrm{ADD}$ or EDI is a parameter used to calculate the oral exposure dosage during a specific period by expressing it as a daily dose per unit body weight [143]. The equation of ADD or EDI in Equations (7) and (8) was formulated as:

$$
\begin{gathered}
\mathrm{ADD}=(\mathrm{C} \times \mathrm{IR} \times \mathrm{EF} \times \mathrm{ED}) /(\mathrm{BW} \times \mathrm{AT}) \\
\mathrm{EDI}=(\mathrm{C} \times \mathrm{CON}) / \mathrm{BW}
\end{gathered}
$$

where $C$ is the heavy metal concentration in rice grain $(\mathrm{mg} / \mathrm{kg})$; Con is the average daily consumption of rice in the region ( $\mathrm{kg} /$ day); and, $\mathrm{BW}$ is the average body weight of people in the region $(\mathrm{kg})$ [144]. IR, ED, EF, and AT represent the ingestion rate, exposure duration, exposure frequency, and averaging time, respectively $[41,145]$. The ADD or EDI of metals rely on the concentration of metal in food and daily amount of food consumed $[41,95,143]$. The EDI of heavy metals via rice ingestion reported by Neeratanaphan et al. [95] was higher than the previous study conducted by Huang et al. [146], which indicates that the rice consumption among local inhabitants in Khong Chai district of the Kalasin Province in Thailand is probably exposed to heavy metal contamination. The average daily intake of rice among adults and children living around Huludao Zinc Plant in China was 389.2 and $198.4 \mathrm{~g} /$ person/day, respectively [87]. Fan et al. [143] reported that the ADD value for Cd is much higher than other heavy metals and suggested a heavy daily intake of $\mathrm{Cd}$ from rice for adult from three main areas of mines (Liuyang, Hengyang, Loudi) of Hunan Province, China. The perennial intake of contaminated rice crops is likely to induce adverse health effects from heavy metal exposures.

\begin{tabular}{|c|c|c|}
\hline Model of Risk Assessment & Mathematical Equation & Description of Equation \\
\hline Health Risk Index (HRI) & $\sum \frac{\mathrm{n}(\mathrm{Cn} \times \mathrm{Dn})}{\mathrm{RfD}-\mathrm{Bw}}$ or $\frac{\mathrm{EDI}}{\mathrm{RfD}}$ & $\begin{array}{c}\text { Cn = Heavy metal concentrations in samples }(\mathrm{mg} / \mathrm{kg}) \\
\text { Dn = Daily intake of samples }(\mathrm{mg} / \text { person } / \text { day }) \\
\text { RfD = Oral reference dose }(\mathrm{mg} / \mathrm{kg} / \text { day }) \\
\text { Bw = Body weight for children and adults }(\mathrm{kg}) \\
\text { EDI = Estimated Daily Intake }(\mathrm{mg} / \mathrm{kg} / \text { day) }\end{array}$ \\
\hline Hazard Index (HI) & $\sum_{\mathrm{i}=1}^{\mathrm{n}} \mathrm{HRI}$ or $\sum \mathrm{HQ}$ & $\begin{array}{l}\text { HRI }=\text { Hazard risk index } \\
H Q=\text { Hazard Quotients }\end{array}$ \\
\hline Hazard Quotient (HQ) & $\frac{\mathrm{ADI}}{\mathrm{RfD}}$ & $\begin{aligned} \mathrm{ADI} & =\text { Average Daily Intake }(\mathrm{mg} / \mathrm{kg} . \text { day }) \\
\mathrm{RfD} & =\text { Oral reference dose }(\mathrm{mg} / \mathrm{kg} / \text { day })\end{aligned}$ \\
\hline $\begin{array}{l}\text { Target Hazard Quotients } \\
\text { (THQ) }\end{array}$ & $\frac{\mathrm{MC} \times \mathrm{FI} \times \mathrm{EFr} \times \mathrm{ED}}{\mathrm{RfD} \times \mathrm{Bw} \times \mathrm{AT}} \times 10^{-3}$ & $\begin{array}{c}\text { MC = Metal concentration in samples }(\mathrm{mg} / \mathrm{kg}) \\
\text { FI = Ingestion rate }(\mathrm{mg} / \text { day } / \text { person) } \\
\mathrm{EFr}=\text { The exposure frequency (days } / \text { year }) \\
\mathrm{ED}=\text { Total exposure duration (years) } \\
\mathrm{RfD}=\text { Oral reference dose }(\mathrm{mg} / \mathrm{kg} / \text { day }) \\
\mathrm{Bw}=\text { Body weight for children and adults }(\mathrm{kg}) \\
\mathrm{AT}=\text { The non-carcinogen averaging time } \\
(\mathrm{ED} \times 365 \text { days } / \text { year })\end{array}$ \\
\hline Cancer Risk (CR) & $\mathrm{ADI} \times \mathrm{SF}$ & $\begin{array}{l}\mathrm{ADI}=\text { Average Daily Intake }(\mathrm{mg} / \mathrm{kg} \cdot \text { day }) \\
\mathrm{SF}=\text { Cancer Slope Factor }(\mathrm{mg} / \mathrm{kg} \cdot \text { day })^{-1}\end{array}$ \\
\hline Target Cancer Risk (TCR) & $\frac{\left(\mathrm{Cb} \times \mathrm{I} \times 10^{-3} \times \mathrm{CPSO} \times \mathrm{EFr} \times \mathrm{EDtot}\right)}{(\mathrm{BWa} \times \mathrm{ATC})}$ & $\begin{array}{c}\mathrm{Cb}=\text { Heavy metal concentrations in samples }(\mathrm{mg} / \mathrm{kg}) \\
\mathrm{I}=\text { The ingestion rate }(\mathrm{mg} / \text { day } / \text { person) } \\
\mathrm{CPSO}=\text { The carcinogenic potency slope, oral }(\mathrm{mg} / \mathrm{g} / \text { day) } \\
\text { EFr }=\text { The exposure frequency }(\text { days } / \text { year }) \\
\text { EDtot }=\text { Total exposure duration (years) } \\
\mathrm{ATC}=\text { The carcinogen averaging time (days/year) ED } \times 365\end{array}$ \\
\hline
\end{tabular}

Table 4. Mathematical models for risk assessment on heavy metal exposure. Adapted from EPA [147]. 


\subsection{Non-Carcinogenic Risk Assessment}

\subsubsection{Health Risk Index (HRI)}

In determining the HRI value, the equation shown in Table 4 involves the ratio between the daily intake of metal through consumption and the oral reference dose, together with general body weight of children and adults [12,106,148-151]. An HRI index value of more than 1 shows that human health is at risk or unsafe [152]. A changing of age in adults and children has determined the observation of health risk. The exposure was observed differently because of the different contact pathway. The health risk between age groups and locality of inhabitants may not be similar. [153]. Table 5 shows non-carcinogenic risk assessment from rice consumption in selected areas of different countries. The findings by Satpathy et al. [32] found that the $\mathrm{Zn}$ element has the highest HRI value in adults, which is beyond the value of 1 . Similar to Neeratanaphan et al. [95], besides $\mathrm{Pb}$, the HRI value for Mn was found to be greater than 1. However, $\mathrm{Zn}$ and Mn are known to be essential micronutrients that are necessary for plant growth; however, the micronutrients can be extremely toxic at high concentrations [154]. Although the health risk of single metal exposure was generally considered to be safe for consumption, the combination of several heavy metals may cause risk to local inhabitants. The exposure to two or more pollutants may result in additive or interactive effects [155].

\subsubsection{Hazard Quotient (HQ) and Target Hazard Quotient (THQ)}

$\mathrm{HQ}$ and $\mathrm{HI}$ are example models that are used to analyze human non-carcinogenic risk for local inhabitants. Besides using total HRI value, the hazard quotient (HQ) also can be used to determine HI. The HQ formula that is shown in Table 4 is almost similar to HRI, where the equation involves the ratio of average daily intake (ADI) and reference dose (RfD) [147]. This equation is able to characterize the health risk of non-carcinogenic adverse effects due to exposure to toxicants $[156,157]$, by which RfD is the estimated allowable dose for human via daily exposure [37]. The target hazard quotient (THQ) is another term used other than HQ to measure the potential non-carcinogenic effects of individual heavy metal [158]. It is used as a method to estimate risk, as provided by USEPA [158] in the U.S EPA Region III risk-based concentration table and the equation involved was based on Chien et al. [159], Yang et al. [160], and Fang et al. [161], as shown in Table 4. If $\mathrm{HQ}$ or $\mathrm{THQ}<1$, adverse health effects would unlikely be experienced, whereas, if $\mathrm{HQ}$ or THQ $\geq 1$, then potential non-carcinogenic effects would occur [37,162,163].

Fan et al. [143] and Zeng et al. [37] reported that the HQ levels of Cd via brown rice consumption for local residents in Hunan Province exceeded 1, which indicated that this could pose potential non-carcinogenic risks for human health and are likely to increase due to the continuing consumption of contaminated brown rice by resident near mines area. Similarly, Wang et al [164] has revealed that the mean value of THQ for Cd exceeded the threshold value. The value indicates that the local inhabitants carry high potential for chronic health risk through rice consumption.

In Nigeria, $\mathrm{HQ}$ for $\mathrm{Cd}$ and $\mathrm{Pb}$ was found $>1$, which will likely induce adverse health effect via rice consumption [146]. In contrast, Horiguchi et al. [165] suggested that heavy metals that are ingested by human are not equal to the absorbed pollutant dose in reality, as some fraction from the ingested heavy metals may be excreted and some of them may remain accumulated in the human body tissues, which could possibly affect their health. Meanwhile, in Iran, Djahed et al. [137] discovered that As has a HQ value more than 1, which indicated a considerable non-carcinogenic adverse health effect and consumption of rice from the collected samples is probably unsafe.

\subsubsection{Hazard Index (HI)}

$\mathrm{HI}$ is calculated through the average daily consumption of rice for individual (adults and children) in order to obtain the measure of the potential risk of adverse health effects from a combination of chemical elements in rice. HRI or HQ can be summed across the constituents, as shown in Table 5, by assuming additive effects in order to calculate the 
hazard index (HI) for a specific receptor combination, such as diet [32,37,122]. Chronic risks are assumed to be unlikely to happen if the value of $\mathrm{HI}<1$, but, in case of the $\mathrm{HI}$ value reaching $\geq 1$, non-cancer risk is likely to occur $[143,166]$.

With reference to Table 5, Satpathy et al. [32] reported the HI values of heavy metals to be 1.561 and 1.360, respectively, for adults and children, in the East Coast Road, India, which indicates that they will undergo poor health effects in the near future due to the biomagnification caused by heavy metal accumulation over a period of time. Song et al. [41] stated the $\mathrm{HI}$ values of rice and vegetables in functional site of three toxic metals $(\mathrm{As}, \mathrm{Pb}$, and $\mathrm{Cd}$ ) were greater than 1 , whereas the $\mathrm{HI}$ values in the control site were less than 1 for adults and children. However, if the pollution continues to be severe in the control site, then it may greatly affect human health risks in their residents' area.

In contrast with China, Zeng et al. [37] found the greater value of HI, which was up to 14.6 after evaluating the brown rice consumption with seven elements $(\mathrm{Cd}, \mathrm{Cr}, \mathrm{As}$, $\mathrm{Ni}, \mathrm{Pb}, \mathrm{Mn}$, and $\mathrm{Hg}$ ). This value means that there is high non-carcinogenic risk from the ingestion of local brown rice. Praveena and Omar [167] found that rice that was collected from markets in Malaysia has a high potential of non-carcinogenic risk based on HI values for both adults and children by 27.0 and 18.0, respectively, through a combination of trace element and heavy metal exposure. Silins and Hogberg [168] suggested that cumulative trace element and heavy metal exposures will increase the health risks more than individual exposure of trace element and heavy metals.

Table 5. Non-carcinogenic risk assessment from rice consumption in selected areas of different countries.

\begin{tabular}{|c|c|c|c|c|c|c|c|c|c|c|}
\hline \multirow{2}{*}{ Area of Study } & \multirow{2}{*}{ HRI/HQ/THQ } & \multirow{2}{*}{ Individuals } & \multicolumn{6}{|c|}{ Risk Values } & \multirow{2}{*}{ HI } & \multirow{2}{*}{ References } \\
\hline & & & As & $\mathbf{P b}$ & $\mathrm{Cd}$ & $\mathrm{Cu}$ & $\mathrm{Cr}$ & $\mathrm{Zn}$ & & \\
\hline \multirow{2}{*}{$\begin{array}{l}\text { East Coast Road, } \\
\text { India }\end{array}$} & \multirow{2}{*}{ HRI } & Adults & - & 0.269 & 0.042 & 0.001 & 0.123 & 1.126 & 1.561 & \multirow{2}{*}{$\begin{array}{c}\text { Satpathy et al. } \\
{[32]}\end{array}$} \\
\hline & & Children & - & 0.234 & 0.036 & 0.001 & 0.108 & 0.981 & 1.360 & \\
\hline $\begin{array}{l}\text { Kalasin Province, } \\
\text { Thailand }\end{array}$ & HRI & $\begin{array}{c}\text { Local } \\
\text { inhabitants }\end{array}$ & - & 1.50 & - & - & 0.30 & - & - & $\begin{array}{l}\text { Neeratanaphan } \\
\text { et al. [95] }\end{array}$ \\
\hline $\begin{array}{c}\text { Hunan Province, } \\
\text { China }\end{array}$ & HQ & $\begin{array}{c}\text { Local } \\
\text { inhabitants }\end{array}$ & 8.18 & 0.045 & 2.29 & - & 0.258 & - & 14.6 & Zeng et al. [37] \\
\hline $\begin{array}{c}\text { Hunan Province, } \\
\text { China }\end{array}$ & HQ & $\begin{array}{c}\text { Local } \\
\text { inhabitants }\end{array}$ & 0.7264 & 0.0484 & 11.798 & - & - & - & - & Fan et al. [143] \\
\hline \multirow{2}{*}{ Fuzhou, China } & \multirow{2}{*}{ THQ } & Adults & 0.8 & 0.1 & 0.6 & 0.3 & 0.00044 & - & 1.9 & \multirow{2}{*}{ Fu et al. [169] } \\
\hline & & Children & 0.8 & 0.1 & 0.6 & 0.3 & 0.00050 & - & 2.0 & \\
\hline \multirow{2}{*}{ Zhejiang, China } & \multirow{2}{*}{ HRI } & Adults & 0.34 & 0.84 & 0.77 & - & - & - & - & \multirow{2}{*}{$\begin{array}{l}\text { Huang et al. } \\
\text { [46] }\end{array}$} \\
\hline & & Children & 0.44 & 1.09 & 1.00 & - & - & - & - & \\
\hline $\begin{array}{l}\text { Hunan Province, } \\
\text { China }\end{array}$ & THQ & $\begin{array}{c}\text { Local } \\
\text { inhabitants }\end{array}$ & - & 0.081 & 3.047 & 0.877 & 0.005 & 0.771 & 8.138 & $\begin{array}{l}\text { Wang et al. } \\
\text { [164] }\end{array}$ \\
\hline Enugu, Nigeria & HQ & Adults & - & 1.11 & 1.20 & - & 0.008 & 0.24 & 3.028 & $\begin{array}{c}\text { Ihedioha et al. } \\
\text { [145] }\end{array}$ \\
\hline \multirow{2}{*}{ Malaysia } & \multirow{2}{*}{ HQ } & Adults & 0.51 & 0.051 & 0.47 & 0.4 & 0.0008 & 0.26 & 27.0 & \multirow{2}{*}{$\begin{array}{c}\text { Praveena and } \\
\text { Omar [167] }\end{array}$} \\
\hline & & Children & 0.33 & 0.11 & 0.3 & 0.25 & 0.005 & 0.17 & 18.0 & \\
\hline Iranshahr, Iran & HQ & $\begin{array}{c}\text { Local } \\
\text { inhabitants }\end{array}$ & 5.23 & 0.14 & 0.15 & 0.32 & - & - & 1.64 & $\begin{array}{c}\text { Djahed et al. } \\
\text { [137] }\end{array}$ \\
\hline
\end{tabular}

Note: Health Risk Index, HRI; Hazard Quotient, HQ; Target Hazard Quotient, THQ; Hazard Index, HI.

\subsection{Carcinogenic Risk Assessment}

Cancer Risk (CR) and Total Cancer Risk (TCR)

For carcinogenic risk assessment, cancer risk (CR) or target cancer risk (TCR) are calculated using the equation that is shown in Table 6 in order to estimate the incremental probability of an individual developing cancer over a lifetime. For example, a CR of $10^{-4}$ indicates a probability of 1 in 10,000 individuals developing cancer [170]. The total CR (CRt) from all carcinogens is summed by assuming the additive effects, if the multiple 
carcinogenic elements are present. USEPA Region III Risk-Based Concentration provided the method of estimating TCR [156]. According to Ma et al. [171] and Cao et al. [166], it is considered acceptable if the risks are in the range of $1.0 \times 10^{-6}$ to $1.0 \times 10^{-4}$.

The International Agency for Research on Cancer (IARC) [4] has categorized As, $\mathrm{Cr}$, and $\mathrm{Cd}$ as carcinogenic to humans, whereas $\mathrm{Pb}, \mathrm{Co}, \mathrm{Cu}, \mathrm{Fe}, \mathrm{Al}$, and $\mathrm{Zn}$ are noncarcinogenic to humans. A study conducted by Fu et al. [169] on the carcinogenic risk of As in rice among Fuzhou population, Jiangxi Province of China, found that the TCR values were slightly higher than the acceptable range, which are $3.5 \times 10^{-4}$ for adults and $3.8 \times 10^{-4}$ for children. The values showed that As was present in the form of inorganic As in rice with $100 \%$ bioaccessibility for consumers. Therefore, the authors concluded that the carcinogenic risk of As might be overestimated, since the percentage of inorganic As is not $100 \%$ in food commodities. The consumption of local brown rice by people in Hunan Province, China poses potentially great carcinogenic risk based on the multiple carcinogenic evaluations, which was up to more than $400 \times$ higher than the limit set by USEPA [156], which is one to one hundred in a million chance of additional human cancer over a 70-year lifetime [37].

Table 6 shows the summary of carcinogenic risk assessment via rice consumption in selected areas of different countries. With reference to the table, the $\mathrm{CR}$ value for $\mathrm{Cd}$ in brown rice grown near the three mining areas of Hunan Province was the highest, with a total cancer risk of 0.0423 in 2015 [37] and 0.1773 in 2017 [143], indicating a great potential of carcinogenic risk from brown rice consumption in this region due to metal mining and waste discharge. For Malaysia, a study on 22 varieties of marketed rice samples to determine both the total and bioaccessibility of heavy metals revealed that the cumulative carcinogenic health risk via rice consumption for the combined exposure of $\mathrm{As}$ and $\mathrm{Pb}$ in adult and children was 0.0049 and 0.0032 , respectively [167]. The findings showed that the exposure from combined heavy metals has a potential carcinogenic risk, especially in children growth development. Zeng et al. [37] and Fan et al. [143] reported that Cd contribute to cancer risk by approximately $99.77 \%$ and $81.2 \%$, respectively. Long-term exposure towards $\mathrm{Cd}$ was reported to lead to an increased risk of mortality from all cancers [172]. Recently, Djahed et al. [137] and Fakhri et al. [173] conducted a study in Iran on the carcinogenic risk assessment from rice consumption among local inhabitants and found that the ingestion of rice for lifetime consumption would induce cancer risk, since the values of $\mathrm{CR}$ for both studies exceed the acceptable range. Hence, the remediation of contaminated soil is one of the effective measures to secure and reduce the risk of the local communities. In addition, it is strongly suggested that a routine monitoring of heavy metals in soil and rice in these areas be implemented.

Table 6. Carcinogenic risk assessment via rice consumption in selected areas of different countries.

\begin{tabular}{|c|c|c|c|c|c|c|c|c|c|}
\hline \multirow{2}{*}{ Area of Study } & \multirow{2}{*}{ CR/TCR } & \multirow{2}{*}{ Individuals } & \multicolumn{5}{|c|}{ Heavy Metals } & \multirow[t]{2}{*}{ CRt } & \multirow[t]{2}{*}{ References } \\
\hline & & & As & $\mathrm{Pb}$ & $\mathrm{Cd}$ & $\mathrm{Ni}$ & $\mathrm{Cr}$ & & \\
\hline $\begin{array}{c}\text { Hunan Province, } \\
\text { China }\end{array}$ & CR & $\begin{array}{c}\text { Local } \\
\text { inhabitants }\end{array}$ & 0.00368 & - & 0.0343 & 0.00393 & 0.000388 & 0.0423 & Zeng et al. [37] \\
\hline $\begin{array}{l}\text { Hunan Province, } \\
\text { China }\end{array}$ & CR & $\begin{array}{c}\text { Local } \\
\text { inhabitants }\end{array}$ & 0.0003 & - & 0.1769 & - & - & 0.1773 & Fan et al. [143] \\
\hline \multirow{2}{*}{ Fuzhou, China } & \multirow{2}{*}{ TCR } & Adult & 0.00035 & - & - & - & - & NA & \multirow{2}{*}{ Fu et al. [169] } \\
\hline & & Children & 0.00038 & - & - & - & - & NA & \\
\hline \multirow{2}{*}{ Malaysia } & \multirow{2}{*}{ CR } & Adult & $>0.0001$ & $<0.0001$ & - & & - & 0.0049 & \multirow{2}{*}{$\begin{array}{c}\text { Praveena and } \\
\text { Omar [167] }\end{array}$} \\
\hline & & Children & $>0.0001$ & $<0.0001$ & - & - & - & 0.0032 & \\
\hline Iranshahr, Iran & CR & $\begin{array}{c}\text { Local } \\
\text { inhabitants }\end{array}$ & 0.00237 & - & - & - & - & NA & $\begin{array}{c}\text { Djahed et al. } \\
\text { [137] }\end{array}$ \\
\hline Iran & CR & $\begin{array}{c}\text { Local } \\
\text { inhabitants }\end{array}$ & 0.04864 & 0.02623 & - & - & - & 0.0749 & Fakhri et al. [173] \\
\hline
\end{tabular}




\subsection{In Vitro Digestion Model}

Other than estimating HRA by mathematical models, in vitro digestion models can be conducted in order to determine the bioaccessible form of trace element and heavy metals $[174,175]$. This model involves the total fraction of trace element and heavy metal concentration present in a specific environmental field within a time period and uptake through the indirect ingestion by organisms [176]. Rijksinstituut voor Volksgezondheid en Milieu (RIVM) in vitro digestion model is an example of the bioavailability method used in rice studies via rice ingestion, where the models involved are quite similar to the physiological conditions in a human body. According to Fernández-García et al. [177], the in vitro model minimizes the use of experimental animals and the massive number of different matrices, which makes it easier to measure a large number of sample and allows for replication.

These kinds of characteristics make it widely applicable for health assessment and nutritional efficiency prediction. There are three compartments that are involved based on the human physiological condition, which are oral cavity, stomach, and small intestine, including the parameters of $\mathrm{pH}$, residence time, and particle size [174]. According to Lee et al. [178], the bioavailability concentrations are much preferred when compared to total heavy metal concentration due to overestimates of human health risks from heavy metal exposure. However, it is insufficient to identify health risks that are posed by humans through consumption by only assessing the bioavailability in rice below the maximum permitted levels. The detailed HRA should be associated with both carcinogenic and non-carcinogenic health risks to understand heavy metal exposure among adults and children [167].

Cooked rice is considered to be the best form of matrix to be used in human health risks studies when compared to raw rice, as the sample must be as if it was ingested by consumers in a way to reflect real situation of human exposure [179]. Omar et al. [174] found that the bioavailability of heavy metal concentration in cooked rice samples was reduced from $\mathrm{Zn}>\mathrm{Fe}>\mathrm{Cu}>\mathrm{Cr}>\mathrm{Cd}$, and all of the varieties of cooked rice samples studied were considered to be safe for human consumption. However, the concentration of harmful heavy metals, such as $\mathrm{Cd}$ and $\mathrm{Cr}$ in low amounts, can potentially risk renal impairment and bone disease, such as osteoporosis in adults, both male and female [51,180]. A study conducted by Yang et al. [181] on Cd bioaccessibility in uncooked rice from rural mining areas revealed that the bioavailability fraction of $\mathrm{Cd}$ in uncooked rice has a significant positive correlation with the total concentration of $\mathrm{Cd}$ in cooked rice. The bioaccessibility of $\mathrm{Cd}$ from food depends not only on its binding forms, but also on the properties of food, such as the source of food and processing method. A recent study by Praveena and Omar [167] reported that the bioaccessibility of trace element and heavy metal concentration in cooked rice samples are below the maximum permitted level set by Malaysian Food Regulation [182] with a decreasing order of $\mathrm{Zn}(4.3 \mathrm{mg} / \mathrm{kg})>\mathrm{Fe}(1.9 \mathrm{mg} / \mathrm{kg})>\mathrm{Cu}$ $(1.1 \mathrm{mg} / \mathrm{kg})>\mathrm{Al}(0.89 \mathrm{mg} / \mathrm{kg})>\mathrm{Cr}(0.11 \mathrm{mg} / \mathrm{kg})>\mathrm{Co}(0.032 \mathrm{mg} / \mathrm{kg})>\mathrm{Cd}(0.027 \mathrm{mg} / \mathrm{kg})$ $>\mathrm{Pb}(0.022 \mathrm{mg} / \mathrm{kg})>\mathrm{As}(0.016 \mathrm{mg} / \mathrm{kg})$.

Furthermore, Praveena and Omar [167] revealed that no potential non-carcinogenic risk was found to exist in adults and children through individual trace element and heavy metal exposure $(\mathrm{HQ}<1)$, but As was found to be present as a potential carcinogenic health risk with a $\mathrm{CR}$ value of more than $1 \times 10^{-4}$. Examples of potential health risk from As exposure from cooked rice grain are malignant neoplasms, melanosis, and depigmentation; hence, concern on children should be more focused, since $\mathrm{As}$ and $\mathrm{Pb}$ can affect their brain and nervous system development [183]. Limitations on the available data for Malaysian ingestion rate (IR) values may influence the HRA, since the study was based on a previous report by Zheng et al. [87].

\section{Mitigation Methods}

There are several preventive measures for reducing heavy metals exposure to human (Table 7), by reducing their concentration in soil, and finally reducing their rice uptake. 
These approaches can be categorized as: (i) agriculture management practices, (a) water management [184], (b) soil amendments [185,186], (c) nutrient management [187], and (d) Tillage management [188], (ii) Bioremediation strategies, (a) Phytoremediation [189], (b) Microbial remediation [190], and (iii) Genetic approaches [191].

Table 7. Mitigation methods for reducing heavy metals availability in rice grains.

\begin{tabular}{lcc}
\hline \multicolumn{1}{c}{ Mitigation Methods } & Heavy Metals & References \\
\hline Agriculture management practices & & Rinklebe et al. [192] \\
\hline $\begin{array}{l}\text { Alternate wet and dry method (AWD) converts As (III) to As (V) } \\
\text { which is less soluble in water; henceforth less uptake by plants }\end{array}$ & As) & Cd et al. [193] \\
\hline $\begin{array}{l}\text { (a) Water management } \\
\text { Flooding before and after heading lessens Cd concentration }\end{array}$ & MeHg, THg & Tanner et al. [194] \\
\hline $\begin{array}{l}\text { AWD states reduced the activity of Hg(II)-methylating microbes } \\
\text { which caused limited MeHg and THg concentrations in rice }\end{array}$ & $\mathrm{As}(\mathrm{III})$ & Wu et al. [195] \\
\hline $\begin{array}{l}\text { Silica strives with As(III) throughout uptake and down } \\
\text { regulates Si transporters in root }\end{array}$ & $\mathrm{Cd}$ & Nwugo and Huerta [196] \\
\hline $\begin{array}{l}\text { Application of silica limited Cd uptake and its accumulation in } \\
\text { rice plants }\end{array}$ & $\mathrm{Pb}$ & Liu et al. [197] \\
\hline $\begin{array}{l}\text { Si and nano Si application limited Pb uptake in rice grain } \\
\text { Application of iron halt soluble Cd and As via formation of Fe } \\
\text { plaques on root surface }\end{array}$ & $\mathrm{Cd}, \mathrm{As}$ & Suriyagoda et al. [198] \\
\hline
\end{tabular}

(b) Soil amendments

Fly Ash addition and Steel Slag lessens the $\mathrm{Pb}$ and $\mathrm{Cd}$ uptake in rice owing to immobilization of heavy metals in soil via in situ

$\mathrm{Pb}, \mathrm{Cd}$

Gu et al. [199]

Reduction of Cd solubility in soil as a result of their high calcium content, total calcium carbonates and alkalinity.
$\mathrm{Cd}$

\section{(c) Nutrient management}

\begin{tabular}{llc}
\hline $\begin{array}{l}\text { Sulphur boosts complexation of As by synthesising Fe plaques } \\
\text { and forming thiols }\end{array}$ & As & Dixit et al. [190] \\
\hline $\begin{array}{l}\text { Application of sulphur declines } \mathrm{Cd} \text { and As uptake due to the } \\
\text { rise of glutathione contents in the plants leaves }\end{array}$ & $\mathrm{Cd}$, As & Fan et al. [201] \\
\hline $\begin{array}{l}\text { Application of phosphorus rises soil } \mathrm{pH} \text { leading to sorption of } \\
\mathrm{Cd} \text { in the soil }\end{array}$ & $\mathrm{Cd}$ & Ahn et al. [202] \\
\hline $\begin{array}{l}\mathrm{PO}_{4}{ }^{3-} \text { ions changed into } \mathrm{Pb}_{5}\left(\mathrm{PO}_{4}\right)_{3} \mathrm{OH} \text { when reacting with } \\
\text { surface-adsorbed } \mathrm{Pb} .\end{array}$ & $\mathrm{Pb}$ Cao et al. [203] \\
\hline $\begin{array}{l}\text { Biochar adsorbs As and make it not available to plants } \\
\text { pH, which encourages Cd precipitation and Cd sorption }\end{array}$ & $\mathrm{As}$ & Yu et al. [204] \\
\hline $\begin{array}{l}\text { Biochar retain Pb in soil as a result of high pH, cation exchange } \\
\text { capacity (CEC), active functional groups, and porosity }\end{array}$ & $\mathrm{Cd}$ & Bian et al. [205] \\
\hline
\end{tabular}

(d) Tillage management

High soil organic condition underneath reduced tillage management can elevate $\mathrm{Cd}$ adsorption and complexation 
Table 7. Cont.

\begin{tabular}{lcc}
\hline \multicolumn{1}{c}{ Mitigation Methods } & Heavy Metals & References \\
\hline Bioremediation strategies & & Seregin et al. [207]; Wei et al. \\
\hline $\begin{array}{l}\text { Plants such as Solanum nigrum, Arabidopsis halleri, and many } \\
\text { others, are classified as Cd hyperaccumulators and meant for } \\
\text { phytoremediation of Cd contaminated sites. }\end{array}$ & Cd et al. [209]
\end{tabular}

\section{(a) Phytoremediation}

Some Azolla like species including Azolla fi liculoides Lam and Azolla caroliniana Willd. accumulates As in their body parts Chinese brake fern known as Pteris vittata L. is a famous As hyperaccumulator

Zhang et al. [210]
Ma et al. [90]

Arbuscular mycorrhizal fungi (AMF) lessen uptake of Cd by rice, via changing chemical forms and subcellular distribution of $\mathrm{Cd}$ in rice

Inoculation of rice with single or combined AMF reduced uptake of As in rice

$\mathrm{Cd}$

Li et al. [211]
Chan et al. [212]

\section{(b) Microbial remediation}

Sarchosphaera coronaria, the ectomychorrizal fungus accumulates As at high levels in its fruiting bodies.

\section{Genetic approaches}

Paracoccus species (aio $A$ gene), the As (III) oxidizing- bacteria like converts As (III) to As (V) which is less mobile and less toxic than As (III). Inoculation of this species not just lessens the burden of As nonetheless encourages rice growth.

As(III), As(V) Zhang et al. [214]

An arsM gene transforms As (III) into methylated species i.e., monomethylarsonic acid (MMA).
As(III)
Suriyagoda et al. [215]

\section{Conclusions}

Most rice producing countries experience heavy metal contamination, owing to human activities such as mining and smelting. Soils are the major sources of heavy metals, and its accumulation in grain is significantly important, as it will be processed for human consumption. Therefore, the health risk assessment on heavy metal exposure can provide an estimation of health risks that would be experienced by the targeted population, including infants and children. In fact, a standard of toxic heavy metal level in infant and children food products should be strictly imposed, as they are more susceptible to toxic metal poisoning. Data on bioavailability of heavy metals in rice grain are still insufficient, especially in high-risk areas, such as China and Japan. Besides, the availability data of the risk factor, such as ingestion rate in local area, should be of concern by relevant authorities for a particular population in a risk exposure assessment. Overall, the extensive study on heavy metal distribution should be done on risk areas of rice cultivation in order to reduce the public health risks and control rice yield for future demand.

Author Contributions: Conceptualization, A.F.A.R. and G.T.; methodology, A.F.A.R. and N.A.M.R.; writing-original draft preparation, Z.Z., N.S.Z. and N.A.M.R.; writing-review and editing, all authors; supervision, A.F.A.R., J.S., M.R.I. and S.M.P.; funding acquisition, A.F.A.R., J.S. and M.R.I. All authors have read and agreed to the published version of the manuscript.

Funding: The present work was funded by the Malaysian Ministry of Higher Education (MOHE) under the High Impact Center of Excellence (HICoE) grant scheme (UPM/ITAFoS/HICoE-2017/FS10/6369114).

Data Availability Statement: Not applicable. 
Acknowledgments: The authors also would like to thank the Ministry of Higher Education for the HICoE rendered to the Institute of Tropical Agriculture and Food Security (ITAFoS), Universiti Putra Malaysia (UPM) and the Faculty of Food Science and Technology, UPM for the facilities rendered.

Conflicts of Interest: The authors declare no conflict of interest.

\section{Abbreviations}

\begin{tabular}{|c|c|}
\hline ADI & acceptable daily intake \\
\hline $\mathrm{AL}$ & aluminum; \\
\hline AMF & arbuscular mycorrhizal fungi \\
\hline As & arsenic \\
\hline $\mathrm{BAF}$ & bioaccumulation factor \\
\hline $\mathrm{BW}$ & body weight \\
\hline $\mathrm{Cd}$ & cadmium \\
\hline CDI & chronic daily intake \\
\hline $\mathrm{cm}$ & centimeter \\
\hline Co & cobalt \\
\hline $\mathrm{COOH}$ & carboxylic acid group \\
\hline $\mathrm{Cr}$ & chromium \\
\hline CR & cancer risk \\
\hline $\mathrm{Cu}$ & copper \\
\hline DIs & daily intake \\
\hline EC & European Commission \\
\hline $\mathrm{EF}$ & enrichment factor; \\
\hline EFSA & European Food Safety Authority; \\
\hline $\mathrm{FAO}$ & Food and Agriculture Organization \\
\hline FAOSTAT & Food and Agriculture Organization Statistics \\
\hline FDA & US Food and Drug Administration \\
\hline $\mathrm{Fe}$ & iron \\
\hline GRiSP & Global Rice Science Partnership \\
\hline $\mathrm{Hg}$ & mercury \\
\hline $\mathrm{HI}$ & hazard index \\
\hline $\mathrm{HM}$ & heavy metal \\
\hline $\mathrm{HQ}$ & hazard quotient \\
\hline HRA & health risk assessment \\
\hline HRI & health risk index \\
\hline IARC & International Agency for Research on Cancer \\
\hline IR & ingestion rate \\
\hline IRRI & International Rice Research Institute \\
\hline JECFA & Joint Expert Committee on Food Additives \\
\hline MMA & monomethylarsonic acid \\
\hline MMT & million metric tons \\
\hline $\mathrm{Mn}$ & manganese \\
\hline $\mathrm{Ni}$ & nickel \\
\hline $\mathrm{Pb}$ & lead \\
\hline $\mathrm{ppb}$ & parts per billion; \\
\hline RfD & oral reference dose \\
\hline RIVM & Rijksinstituut voor Volksgezondheid en Milieu \\
\hline $\mathrm{Sb}$ & antimony \\
\hline TCR & target cancer risk \\
\hline TDI & tolerable daily intake \\
\hline $\mathrm{TF}$ & translocation factor \\
\hline THQ & target hazard quotient \\
\hline USEPA & US Environmental Protection Agency \\
\hline WHO & World Health Organization \\
\hline $\mathrm{Zn}$ & zinc \\
\hline
\end{tabular}




\section{References}

1. Ckamaca, H. Alga growth inhibition by water pollution. Environ. Pollut. 2002, 117, 411-419.

2. Struger, J.; Fletcher, T.; Martos, P.; Ripley, B. Pesticide Concentrations in the Don and Humber River Watersheds 1998-2000; Ontario Ministry of the Environment: Toronto, ON, Canada, 2002; pp. 1-3.

3. Hojsak, I.; Braegger, C.; Bronsky, J.; Campoy, C.; Colomb, V.; Decsi, T.; van Goudoever, J. Heavy metal in Rice. J. Pediatr. Gastroenterol. Nutr. 2015, 60, 142-145. [CrossRef] [PubMed]

4. International Agency for Research on Cancer (IARC). IARC Monographs on the Evaluation of Carcinogenic Risk to Human; International Agency for Research on Cancer: Lyon, France, 2012; Volume 100C.

5. Bánfalvi, G. (Ed.) Heavy metals, trace elements and their cellular effects. In Cellular Effects of Heavy Metals; Springer: New York, NY, USA, 2011; pp. 3-28.

6. Hite, A.H. Heavy metal and rice: A call for regulation. Nutrition 2013, 29, 353-354. [CrossRef] [PubMed]

7. Grund, S.C.; Hanusch, K.; Wolf, H.U. Arsenic and Arsenic Compounds. In Ullmann's Encyclopedia of Industrial Chemistry; Wiley-VCH: Weinheim, Germany, 2005.

8. Chung, J.Y.; Yu, S.D.; Hong, Y.S. Environmental source of arsenic exposure. J. Prev. Med. Public Health 2014, 47, 253-257. [CrossRef]

9. Ayangbenro, A.S.; Babalola, O. A New Strategy for Heavy Metal Polluted Environments: A Review of Microbial Biosorbents. Int. J. Environ. Res. Public Health 2017, 14, 94. [CrossRef] [PubMed]

10. Cao, Z.H.; Hu, Z.Y. Copper contamination in paddy soils irrigated with wastewater. Chemosphere 2000, 41, 3-6. [CrossRef]

11. Fytianos, K.; Katsianis, G.; Triantafyllou, P.; Zachariadis, G. Accumulation of heavy metals in vegetables grown in an industrial area in relation to soil. Bull. Environ. Contam. Toxicol. 2001, 67, 423-430. [CrossRef] [PubMed]

12. Hang, X.; Wang, H.; Zhou, J.; Ma, C.; Du, C.; Chen, X. Risk assessment of potentially toxic element pollution in soils and rice (Oryza sativa) in a typical area of the Yangtze River Delta. Environ. Pollut. 2009, 157, 2542-2549. [CrossRef]

13. Liu, J.; Duan, C.Q.; Zhu, Y.N.; Zhang, X.H.; Wang, C.X. Effect of chemical fertilizers on the fractionation of Cu, Cr and Ni in contaminated soil. Environ. Geol. 2007, 52, 1601-1606. [CrossRef]

14. Chaney, R.L.; Wang, A.S.; Angle, J.S.; McIntosh, M.S. Using Hyperaccumulator Plants to Phytoextract Soil Cd. In Phytoremediation Rhizoremediation; Springer: Dordrecht, The Netherlands, 2005; pp. 103-114.

15. Fangmin, C.; Ningchun, Z.; Haiming, X.; Yi, L.; Wenfang, Z.; Zhiwei, Z.; Mingxue, C. Cadmium and lead contamination in japonica rice grains and its variation among the different locations in southeast China. Sci. Total Environ. 2006, 359, 156-166. [CrossRef] [PubMed]

16. Zhang, M.K.; Ke, Z.X. Heavy metals, phosphorus and some other elements in urban soils of Hangzhou City, China. Pedosphere 2004, 14, 177-185.

17. Tsukahara, T.; Ezaki, T.; Moriguchi, J.; Furuki, K.; Shimbo, S.; Matsuda-Inoguchi, N.; Ikeda, M. Rice as the most influential source of cadmium intake among general Japanese population. Sci. Total Environ. 2003, 305, 41-51. [CrossRef]

18. Shimbo, S.; Zhang, Z.; Watanabe, T.; Nakatsuka, H.; Matsuda-Inoguchi, N.; Higashikawa, K.; Ikeda, M. Cadmium and lead contents in rice and other cereal products in Japan in 1998-2000. Sci. Total Environ. 2001, 281, 165-175. [CrossRef]

19. Yu, H.; Wang, J.; Fang, W.; Yuan, J.; Yang, Z. Cadmium Accumulation in Different Rice Cultivars and Screening for Pollution-safe Cultivars of Rice. Sci. Total Environ. 2006, 370, 302-309. [CrossRef] [PubMed]

20. Arao, T.; Ae, N. Genotypic variations in cadmium levels of rice grain. J. Soil Sci. Plant Nutr. 2003, 49, 473-479. [CrossRef]

21. Li, K.Q.; Liu, J.G.; Lu, X.L. Uptake and distribution of cadmium in different rice cultivars. Agro-Environ. Sci. 2003, $22,529-532$.

22. Li, Z.W.; Zhang, Y.L.; Pan, G.X.; Li, J.M.; Huang, X.M.; Wang, J.F. Grain contents of Cd, Cu and Se by 57 rice cultivars and the risk significance for human dietary uptake. Environ. Sci. 2003, 24, 112-115.

23. Liu, J.G.; Li, K.Q.; Xu, J.K.; Liang, J.S.; Lu, X.L.; Yang, J.L. Interaction of Cd and five mineral nutrients for uptake and accumulation in different rice cultivars and genotypes. Field Crop. Res. 2003, 83, 271-281. [CrossRef]

24. Liu, J.; Liang, J.; Li, K.; Zhang, Z.; Yu, B.; Lu, X.; Yang, J.; Zhu, Q. Correlations between cadmium and mineral nutrients in absorption and accumulation in various genotypes of rice under cadmium stress. Chemosphere 2003, 52, 1467-1473. [CrossRef]

25. Alloway, B.J. Soil factors associated with zinc deficiency in crops and humans. Environ. Geochem. Health 2009, 31, 537-548. [CrossRef]

26. Singh, R.; Singh, D.P.; Kumar, N.; Bhargava, S.K.; Barman, S.C. Accumulation and translocation of heavy metals in soil and plants from fly ash contaminated area. J. Environ. Biol. 2010, 31, 421-430. [PubMed]

27. JECFA, Joint FAO/WHO Expert Committee on Food Additives. Summary and Conclusion. In Proceedings of the Joint FAO/WHO Expert Committee on Food Additives Seventy-Second Meeting, Rome, Italy, 16-25 February 2010.

28. Singh, J.; Upadhyay, S.K.; Pathak, R.K.; Gupta, V. Accumulation of heavy metals in soil and paddy crop (Oryza sativa), irrigated with water of Ramgarh Lake, Gorakhpur, UP, India. Toxicol. Environ. Chem. 2011, 93, 462-473. [CrossRef]

29. Mido, Y.; Satake, M. Chemicals in the environment. In Toxic Metals; Sethi, M.S., Iqbal, S.A., Eds.; Discovery Publishing House: New Delhi, India, 2003; pp. 45-68.

30. Liu, W.X.; Liu, J.W.; Wu, M.Z.; Li, Y.; Zhao, Y.; Li, S.R. Accumulation and translocation of toxic heavy metals in winter wheat (Triticum aestivum L.) growing in agricultural soil of Zhengzhou, China. Bull. Environ. Contam. Toxicol. 2009, 82, 343-347. [CrossRef]

31. Looi, L.Y.; Aris, A.Z.; Lim, W.Y.; Haris, H. Bioconcentration and Translocation Efficiency of Metals in Paddy (Oryza sativa): A Case Study from Alor Setar, Kedah, Malaysia. Sains Malays. 2014, 43, 521-528. 
32. Satpathy, D.; Reddy, M.V.; Dhal, S.P. Risk Assessment of Heavy Metals Contamination in Paddy Soil, Plants, and Grains (Oryza sativa L.) at the East Coast of India. BioMed Res. Int. 2014, 2014, 1-11. [CrossRef] [PubMed]

33. Hopkins, W.G. Introduction to Plant Physiology, 2nd ed.; John Wiley \& Sons: New York, NY, USA, 1999.

34. Tripathi, R.M.; Raghunath, R.; Krishnamoorthy, T.M. Dietary intake of heavy metals in Bombay city, India. Sci. Total Environ. 1997, 208, 149-159. [CrossRef]

35. Jarvis, S.C.; Jones, L.H.P.; Hopper, M.J. Cadmium uptake from solution by plants and its transport from roots to shoots. Plant Soil 1976, 44, 179-191. [CrossRef]

36. Sanitá Di Toppi, L.; Gabbrielli, R. Response to cadmium in higher plants. Environ. Exper. Bot. 1999, 41, 105-130. [CrossRef]

37. Zeng, F.; Wei, W.; Li, M.; Huang, R.; Yang, F.; Duan, Y. Heavy Metal Contamination in Rice-Producing Soils of Hunan Province, China and Potential Health Risks. Int. J. Environ. Res. Public Health 2015, 12, 15584-15593. [CrossRef]

38. Liu, Y.; Xiao, T.; Baveye, P.C.; Zhu, J.; Ning, Z.; Li, H. Potential health risk in areas with high naturally-occurring cadmium background in south western China. Ecotoxicol. Environ. Saf. 2015, 112, 122-131. [CrossRef]

39. Saha, N.; Rahman, M.S.; Jolly, Y.N.; Rahman, A.; Sattar, M.A.; Hai, M.A. Spatial distribution and contamination assessment of six heavy metals in soils and their transfer into mature tobacco plants in Kushtia District, Bangladesh. In Environmental Science and Pollution Research; Springer: Berlin, Germany, 2015.

40. Zhao, K.; Fu, W.; Ye, Z.; Zhang, C. Contamination and Spatial Variation of Heavy Metals in the Soil-Rice System in Nanxun County, Southeastern China. Int. J. Environ. Res. Public Health 2015, 12, 1577-1594. [CrossRef] [PubMed]

41. Song, D.; Zhuang, D.; Jiang, D.; Fu, J.; Wang, Q. Integrated Health Risk Assessment of Heavy Metals in Suxian County, South China. Int. J. Environ. Res. Public Health 2015, 12, 7100-7117. [CrossRef] [PubMed]

42. Plumlee, K.H. Toxicosis from agricultural chemicals. Clin. Tech. Equine. Pract. 2002, 1, 94-97. [CrossRef]

43. Huang, S.S.; Liao, Q.L.; Hua, M.; Wu, X.M.; Bi, K.S.; Yan, C.Y.; Chen, B.; Zhang, X.Y. Survey of heavy metal pollution and assessment of agricultural soil in Yangzhong district, Jiang Su Province, China. Chemosphere 2007, 67, 2148-2155. [CrossRef]

44. Liu, X.M.; Wu, J.J.; Xu, J.M. Characterizing the risk assessment of heavy metals and sampling uncertainty analysis in paddy field by geostatistics and GIS. Environ. Pollut. 2006, 141, 257-264. [CrossRef] [PubMed]

45. Choi, E.M.; Yang, J.Y.; Yoon, H.J.; Park, K.S. Safety assessment of heavy metals in rice, cultivated habitats (soil and water, etc.) and cooked rice that may arise from environment. Int. J. Res. Chem. Metall. Civil Eng. 2015, 2, 2.

46. Huang, Z.; Pan, X.; Wu, P.; Han, J.; Chen, Q. Health Risk Assessment of Heavy Metals in Rice to the Population in Zhejiang, China. PLoS ONE 2013, 8, e75007. [CrossRef] [PubMed]

47. Marin, A.R.; Masscheleyn, P.; Patrick, W.H. Soil redox-pH stability of arsenic species and its influence on arsenic uptake by rice. Plant Soil 1993, 152, 245-253. [CrossRef]

48. Williams, P.N.; Villada, A.; Deacon, C.; Raab, A.; Figuerola, J.; Green, A.J.; Feldmann, J.; Meharg, A.A. Greatly Enhanced Arsenic Shoot Assimilation in Rice Leads to Elevated Grain Levels Compared to Wheat and Barley. Environ. Sci. Technol. 2007, 41, 6854-6859. [CrossRef]

49. Du, Y.; Hu, X.; Wu, X.; Shu, Y.; Jiang, Y.; Yan, X. Effects of mining activities on Cd pollution to the paddy soils and rice grain in Hunan province, Central South China. Environ. Monit. Assess. 2013, 185, 9843-9856. [CrossRef]

50. Khairiah, J.; Ramlee, A.R.; Jamil, H.; Ismail, Z.; Ismail, B.S. Heavy Metal Content of Paddy Plants in Langkawi, Kedah, Malaysia. Aust. J. Basic Appl. Sci. 2013, 7, 123-127.

51. Yap, D.W.; Adezrian, J.; Khairiah, J.; Ismail, B.S.; Ahmad-Mahir, R. The uptake of heavy metals by paddy plants (Oryza sativa) in Kota Marudu, Sabah, Malaysia. Am.-Eurasian J. Agric. Environ. Sci. 2009, 6, 16-19.

52. Aziz, R.A.; Rahim, S.A.; Sahid, I.; Idris, W.M. Speciation and Availability of Heavy Metals on Serpentinized Paddy Soil and Paddy Tissue. Procedia Soc. Behav. Sci. 2015, 195, 1658-1665. [CrossRef]

53. Payus, C.; Abu-Talip, A.F.; Tan, W.H. Heavy Metals Accumulation in Paddy Cultivation Area of Kompipinan, Papar District, Sabah. J. Sustain. Sci. Manag. 2015, 10, 76-86.

54. Bhattacharyya, P.; Chakraborty, A.; Chakrabarti, K.; Tripathy, S.; Powell, M.A. Chromium Uptake by Rice and Accumulation in Soil Amended with Municipal Solid Waste Compost. Chemosphere 2005, 60, 1481-1486. [CrossRef]

55. Jiang, W.; Struik, P.C.; Lingna, J.; Van-Keulen, H.; Ming, Z.; Stomph, T.J. Uptake and Distribution of Root-applied or Foliarapplied Zinc after Flowering in Aerobic Rice. Ann. Appl. Biol. 2007, 150, 383-391. [CrossRef]

56. Usman, K.; Al-Ghouti, M.A.; Abu-Dieyeh, M.H. Phytoremediation: Halophytes as Promising Heavy Metal Hyperaccumulators. In Heavy Metals; BoD: Norderstedt, Germany, 2018.

57. Muthusaravanan, S.; Sivarajasekar, N.; Vivek, J.S.; Paramasivan, T.; Naushad, M.; Prakashmaran, J.; Gayathri, V.; Al-Duaij, O.K. Phytoremediation of heavy metals: Mechanisms, methods and enhancements. Environ. Chem. Lett. 2018, 16, 1339-1359. [CrossRef]

58. Mishra, S.R.; Chandra, R.; Kaila, J. Kinetics and isotherm studies for the adsorption of metal ions onto two soil types. Environ. Technol. Innov. 2017, 7, 87-101. [CrossRef]

59. Sychta, K.; Słomka, A.; Suski, S.; Fiedor, E.; Gregoraszczuk, E.; Kuta, E. Suspended cells of metallicolous and nonmetallicolous Viola species tolerate, accumulate and detoxify zinc and lead. Plant Physiol. Biochem. 2018, 132, 666-674. [CrossRef]

60. Chandra, S.; Gusain, Y.S.; Bhatt, A. Metal hyperaccumulator plants and environmental pollution. In Microbial Biotechnology in Environmental Monitoring and Cleanup; IGI Global: Hershey, PA, USA, 2018; pp. 305-317. 
61. Vondráčková, S.; Tlustoš, P.; Száková, J. Can liming change root anatomy, biomass allocation and trace element distribution among plant parts of Salix $\times$ smithiana in trace element-polluted soils? Environ. Sci. Pollut. Res. Int. 2017, 24, 19201-19210. [CrossRef]

62. Yaghoubian, Y.; Siadat, S.A.; Telavat, M.R.M.; Pirdashti, H.; Yaghoubian, I. Bio-removal of cadmium from aqueous solutions by filamentous fungi: Trichoderma spp. and Piriformospora indica. Environ. Sci. Pollut. Res. Int. 2019, 26, 7863-7872. [CrossRef]

63. Hassan, F.I.; Niaz, K.; Khan, F.; Maqbool, F.; Abdollahi, M. The relation between rice consumption, arsenic contamination, and prevalence of diabetes in South Asia. EXCLI J. 2017, 16, 1132. [PubMed]

64. Zhao, F.; Zhu, Y.; Meharg, A.A. Methylated Arsenic Species in Rice: Geographical Variation, Origin, and Uptake Mechanisms. Environ. Sci. Technol. 2013, 47, 3957-3966. [CrossRef]

65. Jaishankar, M.; Tseten, T.; Anbalagan, N.; Mathew, B.B.; Beeregowda, K.N. Toxicity, mechanism and health effects of some heavy metals. Interdiscip. Toxicol. 2014, 7, 60-72. [CrossRef]

66. Verbruggen, N.; Hermans, C.; Schat, H. Mechanisms to cope with arsenic or cadmium excess in plants. Curr. Opin. Plant Biol. 2009, 12, 364-372. [CrossRef]

67. Ali, W.; Isayenkov, S.V.; Zhao, F.; Maathuis, F.J. Arsenite transport in plants. Cell. Mol. Life Sci. 2009, 66, 2329-2339. [CrossRef] [PubMed]

68. Liu, J.; Leng, X.; Wang, M.; Zhu, Z.; Dai, Q. Iron plaque formation on roots of different rice cultivars and the relation with lead uptake. Ecotoxicol. Environ. Saf. 2011, 74, 1304-1309. [CrossRef]

69. Uraguchi, S.; Fujiwara, T. Cadmium transport and tolerance in rice: Perspectives for reducing grain cadmium accumulation. Rice 2012, 5, 1-8. [CrossRef] [PubMed]

70. Zenk, M.H. Heavy metal detoxification in higher plants-a review. Gene 1996, 179, 21-30. [CrossRef]

71. Cobbett, C.S. Phytochelatins and their roles in heavy metal detoxification. Plant Physiol. 2000, 123, 825-832. [CrossRef] [PubMed]

72. Chandrasekhar, C.; Ray, J.G. Lead accumulation, growth responses and biochemical changes of three plant species exposed to soil amended with different concentrations of lead nitrate. Ecotoxicol. Environ. Saf. 2019, 171, 26-36. [CrossRef]

73. Sumiahadi, A.; Acar, R. A review of phytoremediation technology: Heavy metals uptake by plants. In IOP Conference Series: Earth and Environmental Science; IOP Publishing: Bristol, UK, 2018; Volume 142, p. 012023.

74. Budzyńska, S.; Mleczek, P.; Szostek, M.; Goliński, P.; Niedzielski, P.; Kaniuczak, J.; Mleczek, M. Phytoextraction of arsenic forms in selected tree species growing in As-polluted mining sludge. J. Environ. Sci. Health A 2019, 54, 933-942. [CrossRef] [PubMed]

75. Shukla, A.; Srivastava, S. Emerging aspects of bioremediation of arsenic. In Green Technologies and Environmental Sustainability; Springer: Cham, Switzerland, 2017; pp. 395-407.

76. Kutrowska, A.; Małecka, A.; Piechalak, A.; Masiakowski, W.; Hanć, A.; Barałkiewicz, D.; Andrzejewska, B.; Zbierska, J.; Tomaszewska, B. Effects of binary metal combinations on zinc, copper, cadmium and lead uptake and distribution in Brassica juncea. J. Trace Elem. Med. Biol. 2017, 44, 32-39. [CrossRef] [PubMed]

77. Ying, M.; Yasuda, H.; Kobayashi, S.; Sakurai, N.; Kidou, S.I. Barley cold-induced CISP proteins contribute to the accumulation of heavy metals in roots. Environ. Exp. Bot. 2019, 165, 53-58. [CrossRef]

78. Bashir, M.; Khalid, S.; Rashid, U.; Adrees, M.; Ibrahim, M.; Islam, M.S. Assessment of Selected Heavy Metals Uptake from Soil by Vegetation of Two Areas of District Attock, Pakistan. Asian J. Chem. 2014, 26, 4. [CrossRef]

79. Mahmod-ul-Hassan, M.; Suthar, V.; Ahmad, R.; Yousra, M. Heavy metal phytoextraction-natural and EDTA-assisted remediation of contaminated calcareous soils by sorghum and oat. Environ. Monit. Assess. 2017, 189, 591. [CrossRef]

80. Suman, J.; Uhlik, O.; Viktorova, J.; Macek, T. Phytoextraction of heavy metals: A promising tool for clean-up of polluted environment? Front. Plant Sci. 2018, 9, 1476. [CrossRef]

81. Rycewicz-Borecki, M.; McLean, J.E.; Dupont, R.R. Nitrogen and phosphorus mass balance, retention and uptake in six plant species grown in stormwater bioretention microcosms. Ecol. Eng. 2017, 99, 409-416. [CrossRef]

82. Kumar, M.; Gupta, N.; Ratn, A.; Awasthi, Y.; Prasad, R.; Trivedi, A.; Trivedi, S.P. Biomonitoring of Heavy Metals in River Ganga Water, Sediments, Plant, and Fishes of Different Trophic Levels. Biol. Trace Elem. Res. 2019, 193, 536-547. [CrossRef] [PubMed]

83. Simate, G.S. Biodegradable Polymer-Carbon Nanotube Composites for Water and Wastewater Treatments. In Handbook of Composites from Renewable Materials; Wiley: Hoboken, NJ, USA, 2017; pp. 15-33.

84. Shrestha, P.; Bellitürk, K.; Görres, J.H. Phytoremediation of Heavy Metal-Contaminated Soil by Switchgrass: A Comparative Study Utilizing Different Composts and Coir Fiber on Pollution Remediation, Plant Productivity, and Nutrient Leaching. Int. J. Environ. Res. Public Health 2019, 16, 1261. [CrossRef]

85. Guo, J.; Feng, R.; Ding, Y.; Wang, R. Applying carbon dioxide, plant growth-promoting rhizobacterium and EDTA can enhance the phytoremediation efficiency of ryegrass in a soil polluted with zinc, arsenic, cadmium and lead. J. Environ. Manag. 2014, 141, 1-8. [CrossRef] [PubMed]

86. Steinberg, S.; Hodge, V. Copper Complexation by Dissolved Organic Matter in arid Soils: A Voltametric Study. Environments 2018, 5, 125. [CrossRef]

87. Zheng, N.; Wang, Q.C.; Zheng, D.M. Health risk of $\mathrm{Hg}, \mathrm{Pb}, \mathrm{Cd}, \mathrm{Zn}$, and $\mathrm{Cu}$ to the inhabitants around Huludao Zinc Plant in China via consumption of vegetables. Sci. Total Environ. 2007, 383, 81-89. [CrossRef] [PubMed]

88. Bu-Olayan, A.H.; Thomas, B.V. Translocation and Bioaccumulation of Trace Metals in Desert Plants of Kuwait Governorates. Int. Res. J. Environ. 2009, 3, 581-587. [CrossRef] 
89. Liu, H.Y.; Probst, A.; Liao, B.H. Metal contamination of soils and crops affected by the Chenzhou lead/zinc mine spill (Hunan, China). Sci. Total Environ. 2005, 339, 153-166. [CrossRef]

90. Ma, L.Q.; Komar, K.M.; Tu, C.; Zhang, W.; Cai, Y.; Kenelly, E.D. A fern that hyper accumulates arsenic. Nature 2001, 409, 579-582. [CrossRef]

91. Cluis, C. Junk-greedy greens: Phytoremediation as a new option for soil decontamination. Biotechnol. J. $2004,2,60-67$.

92. Van der Ent, A.; Baker, A.J.M.; Reeves, R.D.; Pollard, A.J.; Schat, H. Hyperaccumulators of metal and metalloid trace elements: Facts and fiction. Plant Soil 2013, 362,319-334. [CrossRef]

93. Rascio, N.; Navari-Izzo, F. Heavy metal hyperaccumulating plants: How and why do they do it? and what makes them so interesting? Plant Sci. 2011, 180, 169-181. [CrossRef]

94. Zhuang, P.; McBrideb, M.B.; Xiaa, H.; Lia, N.; Lia, Z. Health risk from heavy metals via consumption of food crops in the vicinity of Dabaoshan mine, South China. Sci. Total Environ. 2009, 407, 1551-1561. [CrossRef]

95. Neeratanaphan, L.; Khamma, S.; Benchawattananon, R.; Ruchuwararak, P.; Appamaraka, S.; Intamat, S. Heavy metal accumulation in rice (Oryza sativa) near electronic waste dumps and related human health risk assessment. Hum. Ecol. Risk Assess. 2017, 23, 1086-1098. [CrossRef]

96. Lorestani, B.; Cheraghi, M.; Yousefi, N. Accumulation of Pb, Fe, Mn, Cu and Zn in Plants and Choice of Hyperaccumulator Plants in the Industrial Town of Vian, Iran. Arch. Biol. Sci. 2011, 63, 739-745. [CrossRef]

97. Xie, Z.M.; Huang, C.Y. Control of arsenic toxicity in rice plants grown on an arsenic-polluted paddy soil. Common Soil Sci. Plant Anal. 1998, 29, 2471-2477. [CrossRef]

98. Xie, W.; Che, L.; Zhou, G.; Yang, L.; Hu, M. The bioconcentration ability of heavy metal research for 50 kinds of rice under the same test conditions. Environ. Monit. Assess. 2016, 188, 675. [CrossRef]

99. Rahimi, G.; Kolahchi, Z.; Charkhabi, A. Uptake and translocation of some heavy metals by rice crop (Oryza sativa) in paddy soils. Agriculture (Pol'nohospodárstvo) 2017, 63, 163-175. [CrossRef]

100. Kalavrouziotis, I.K.; Koukoulakis, P.; Kostakioti, E. Assessment of metal transfer factor under irrigation with treated municipal wastewater. Agric. Water Manag. 2012, 103, 114-119. [CrossRef]

101. Barman, S.C.; Sahu, R.K.; Bhargava, S.K.; Chaterjee, C. Distribution of heavy metals in wheat, mustard, and weed grown in field irrigated with industrial effluents. Bull. Environ. Contam. Toxicol. 2000, 64, 489-496. [CrossRef] [PubMed]

102. Gupta, S.; Nayek, S.; Saha, R.N.; Satpati, S. Assessment of heavy metal accumulation in macrophyte, agricultural soil, and crop plants adjacent to discharge zone of sponge iron factory. Environ. Geol. 2008, 55, 731-739. [CrossRef]

103. Rezvani, M.; Zaefarian, F. Bioaccumulation and Translocation Factors of Cadmium and Lead in Aeluropus littoralis. Aust. J. Agric. Eng. 2011, 2, 114-119.

104. Khan, S.; Cao, Q.; Zheng, Y.M.; Huang, Y.Z.; Zhu, Y.G. Health risks of heavy metals in contaminated soils and food crops irrigated with wastewater in Beijing, China. Environ. Pollut. 2008, 152, 686-692. [CrossRef]

105. Dean, J.R. Bioavailability, Bioaccessibility and Mobility of Environmental Contaminants, 1st ed.; John Wiley \& Sons: Hoboken, NJ, USA, 2007.

106. Cui, Y.; Zhu, Y.; Zhai, R.; Chen, D.; Huang, Y.; Qiu, Y.; Liang, J. Transfer of metals from soil to vegetables in an area near a smelter in Nanning, China. Environ. Int. 2004, 30, 785-791. [CrossRef] [PubMed]

107. Rubio, M.I.; Escrig, I.; Martínez-Cortina, C.; Lo'pez-Benet, F.J.; Sanz, A. Cadmium and nickel accumulation in rice plant. Effects on mineral nutrition and possible interactions of abscisic and gibberellic acids. Plant Growth Regul. 1994, 14, 151-157. [CrossRef]

108. Lee, J.S.; Chon, H.T.; Kim, K.M. Migration and dispersion of trace elements in the rock-soil-plant in areas underlain by black shales of the Okchon Zone, Korea. J. Geochem. Explor. 1998, 65, 61-78. [CrossRef]

109. Prasad, M.N.; de Oliveira-Freitas, H.M. Metal hyperaccumulation in plants-Biodiversity prospecting for phytoremediation technology. Electron. J. Biotechnol. 2003, 6, 285-321. [CrossRef]

110. Koźmińska, A.; Wiszniewska, A.; Hanus-Fajerska, E.; Muszyńska, E. Recent strategies of increasing metal tolerance and phytoremediation potential using genetic transformation of plants. Plant Biotechnol. Rep. 2018, 12, 1-14. [CrossRef]

111. Jeong, J.S.; Kim, Y.S.; Baek, K.H.; Jung, H.; Ha, S.H.; Choi, Y.D.; Kim, M.; Reuzeau, C.; Kim, J.K. Root-Specific Expression of OsNAC10 Improves Drought Tolerance and Grain Yield in Rice under Field Drought Conditions. Plant Physiol. 2010, 153, 185-197. [CrossRef]

112. Kisku, G.C.; Barman, S.C.; Bhargava, S.K. Contamination of soil and plants with potentially toxic elements irrigated with mixed industrial effluent and its impact on the environment. Water Air Soil Pollut. 2000, 120, 121-137. [CrossRef]

113. Barman, S.C.; Bhargava, S.K. Accumulation of heavy metals in soil and plants in industrially polluted fields. In Ecological Issues and Environmental Impact Assessment; Cheremissinoff, P.N., Ed.; Gulf Publishing Company: Houston, TX, USA, 1997 ; pp. 289-314.

114. Silva, F.; Stevens, C.J.; Weisskopf, A.; Castillo, C.; Qin, L.; Bevan, A.; Fuller, D.Q. Modelling the Geographical Origin of Rice Cultivation in Asia Using the Rice Archaeological Database. PLoS ONE 2015, 10, e0137024. [CrossRef]

115. Rauscher-Gabernig, E.; Mischek, D.; Moche, W.; Prean, M. Dietary intake of dioxins, furans and dioxin-like PCBs in Austria. Food Addit. Contam. Part A 2013, 30, 1770-1779. [CrossRef]

116. Agency for Toxic Substances and Disease Registry (ATSDR). CERCLA Priority List of Hazardous Substances. 2007. Available online: http:/ / www.atsdr.cdc.gov/cercla/07list.html (accessed on 1 July 2018).

117. Wang, M.; Xu, Y.; Pan, S.; Zhang, J.; Zhong, A.; Song, H.; Ling, W. Long-Term Heavy Metal Pollution and Mortality in a Chinese Population: An Ecologic Study. Biol. Trace Elem. Res. 2011, 142, 362-379. [CrossRef] [PubMed] 
118. Aoshima, K. Itai-Itai Disease: Cadmium-Induced Renal Tubular Osteomalacia. Nippon Eiseigaku Zasshi. Jpn. J. Hyg. 2012, 67, 455-463. [CrossRef] [PubMed]

119. Horiguchi, H. Current Status of Cadmium Exposure among Japanese, Especially Regarding the Safety Standard for Cadmium Concentration in Rice and Adverse Effects on Proximal Renal Tubular Function Observed in Farmers Exposed to Cadmium through Consumption of Self-Grown Rice. Nippon Eiseigaku Zasshi (Jpn. J. Hyg) 2012, 67, 447-454.

120. Horiguchi, H.; Aoshima, K.; Oguma, E.; Sasaki, S.; Miyamoto, K.; Hosoi, Y.; Katoh, T.; Kayama, F. Latest status of cadmium accumulation and its effects on kidneys, bone, and erythropoiesis in inhabitants of the formerly cadmium-polluted Jinzu River Basin in Toyama, Japan, after restoration of rice paddies. Int. Arch. Occup. Environ. Health 2010, 83, 953-970. [CrossRef] [PubMed]

121. Swaddiwudhipong, W.; Limpatanachote, P.; Mahasakpan, P.; Krintratun, S.; Padungtod, C. Cadmium-exposed population in Mae Sot District, Tak Province: 1. Prevalence of high urinary cadmium levels in the adults. J. Med. Assoc. Thail. 2007, 90, 143-148.

122. Hu, B.; Wang, J.; Jin, B.; Li, Y.; Shi, Z. Assessment of the potential health risks of heavy metals in soils in a coastal industrial region of the Yangtze River Delta. Environ. Sci. Pollut. Res. 2017, 24, 19816-19826. [CrossRef] [PubMed]

123. Niu, L.; Yang, F.; Xu, C.; Yang, H.; Liu, W. Status of metal accumulation in farmland soils across China: From distribution to risk assessment. Environ. Pollut. 2013, 176, 55-62. [CrossRef]

124. Pan, J.; Plant, J.A.; Voulvoulis, N.; Oates, C.J.; Ihlenfeld, C. Cadmium levels in Europe: Implications for human health. Environ. Geochem. Health 2010, 32, 1-12. [CrossRef] [PubMed]

125. Swaddiwudhipong, W.; Limpatanachote, P.; Nishijo, M.; Honda, R.; Mahasakpan, P.; Krintratun, S. Cadmium-Exposed Population in Mae Sot District, Tak Province: 3. Associations between Urinary Cadmium and Renal Dysfunction, Hypertension, Diabetes, and Urinary Stones. J. Med. Assoc. Thail. 2010, 93, 231-238.

126. Huang, C.F.; Yang, C.Y.; Chan, D.C.; Wang, C.C.; Huang, K.H.; Wu, C.C.; Tsai, K.-S.; Yang, R.-S.; Liu, S.H. Arsenic exposure and glucose intolerance/insulin resistance in estrogen-deficient female mice. Environ. Health Perspect. 2015, 123, 1138-1144. [CrossRef]

127. Jayasumana, C.; Fonseka, S.; Fernando, A.; Jayalath, K.; Amarasinghe, M.; Siribaddana, S.; Gunatilake, S.; Paranagama, P. Phosphate fertilizer is a main source of arsenic in areas affected with chronic kidney disease of unknown etiology in Sri Lanka. SpringerPlus 2015, 4, 90. [CrossRef]

128. Pourrut, B.; Shahid, M.; Camille, D.; Peter, W.; Eric, P. Lead uptake, toxicity and detoxification in plants. Rev. Environ. Contam. Toxicol. 2011, 213, 113-136. [PubMed]

129. Martin, M.B.; Reiter, R.; Pham, T.; Avellanet, Y.R.; Camara, J. Estrogen-like activity of metals in Mcf-7 breast cancer cells. Endocrinology 2003, 144, 2425-2436. [CrossRef] [PubMed]

130. Hu, W.; Huang, B.; He, Y.; Kalkhajeh, Y.K. Assessment of potential health risk of heavy metals in soils from a rapidly developing region of China. Hum. Ecol. Risk. Assess. 2016, 22, 211-225. [CrossRef]

131. Man, Y.B.; Sun, X.L.; Zhao, Y.G.; Lopez, B.N.; Chung, S.S.; Wu, S.C.; Cheung, K.C.; Wong, M.H. Health risk assessment of abandoned agricultural soils based on heavy metal contents in Hong Kong, the world's most populated city. Environ. Int. 2010, 36, 570-576. [CrossRef]

132. Zota, A.R.; Schaider, L.A.; Ettinger, A.S.; Wright, R.O.; Shine, J.P.; Spengler, J.D. Metal sources and exposures in the homes of young children living near a mining impacted Superfund site. J. Expo. Sci. Environ. Epidemiol. 2011, 21, 495-505. [CrossRef]

133. Qu, C.; Sun, K.; Wang, S.; Huang, L.; Bi, J. Monte Carlo Simulation-Based Health Risk Assessment of Heavy Metal Soil Pollution: A Case Study in the Qixia Mining Area, China. Hum. Ecol. Risk Assess. 2012, 18, 733-750. [CrossRef]

134. Zulkafflee, N.S.; Redzuan, N.A.M.; Selamat, J.; Ismail, M.R.; Praveena, S.M.; Razis, A.F.A. Evaluation of heavy metal contamination in paddy plants at the Northern region of Malaysia using ICPMS and its risk as-sessment. Plants 2021, 10, 3. [CrossRef]

135. Qu, C.; Li, B.; Wu, H.; Wang, S.; Li, F. Probabilistic ecological risk assessment of heavy metals in sediments from China's major aquatic bodies. Stoch. Environ. Res. Risk Assess. 2015, 30, 271-282. [CrossRef]

136. Kentel, E.; Aral, M.M. Probabilistic-fuzzy health risk modeling. Stoch. Environ. Res. Risk Assess. 2004, 18, 324-338. [CrossRef]

137. Djahed, B.; Taghavi, M.; Farzadkia, M.; Norzaee, S.; Miri, M. Stochastic exposure and health risk assessment of rice contamination to the heavy metals in the market of Iranshahr, Iran. Food Chem. Toxicol. 2018, 115, 405-412. [CrossRef]

138. Liang, Y.; Yi, X.; Dang, Z.; Wang, Q.; Luo, H.; Tang, J. Heavy Metal Contamination and Health Risk Assessment in the Vicinity of a Tailing Pond in Guangdong, China. Int. J. Environ. Res. Public Health 2017, 14, 1557. [CrossRef]

139. Fu, S.; Wei, C.Y. Multivariate and spatial analysis of heavy metal sources and variations in a large old antimony mine, China. J. Soils Sediments 2012, 13, 106-116. [CrossRef]

140. United States Environmental Protection Agency (USEPA). Integrated Risk Information System (IRIS); United States Environmental Protection Agency: Washington, DC, USA, 2010. Available online: www.epa.gov/ncea/iris/index.html (accessed on 1 July 2018).

141. Wang, Z.; Chai, L.; Yang, Z.; Wang, Y.; Wang, H. Identifying Sources and Assessing Potential Risk of Heavy Metals in Soils from Direct Exposure to Children in a Mine-Impacted City, Changsha, China. J. Environ. Qual. 2010, 39, 1616. [CrossRef]

142. Xiao, R.; Wang, S.; Li, R.; Wang, J.J.; Zhang, Z. Soil heavy metal contamination and health risks associated with artisanal gold mining in Tongguan, Shaanxi, China. Ecotoxicol. Environ. Saf. 2017, 141, 17-24. [CrossRef] [PubMed]

143. Fan, Y.; Zhu, T.; Li, M.; He, J.; Huang, R. Heavy Metal Contamination in Soil and Brown Rice and Human Health Risk Assessment near Three Mining Areas in Central China. J. Healthc. Eng. 2017, 2017, 4124302. [CrossRef]

144. Fu, J.; Zhou, Q.; Liu, J.; Liu, W.; Wang, T.; Zhang, Q.; Jiang, G. High levels of heavy metals in rice (Oryza sativa L.) from a typical E-waste recycling area in southeast China and its potential risk to human health. Chemosphere 2008, 71, 1269-1275. [CrossRef] [PubMed] 
145. Ihedioha, J.N.; Ujam, O.T.; Nwuche, C.O.; Ekere, N.R.; Chime, C.C. Assessment of heavy metal contamination of rice grains (Oryza sativa) and soil from Ada field, Enugu, Nigeria: Estimating the human healtrisk. Hum. Ecol. Risk Assess. 2016, 22, $1665-1677$. [CrossRef]

146. Huang, P.M.; Gobran, G.R. Biogeochemistry of Trace Elements in the Rhizosphere; Elsevier: Amsterdam, The Netherlands, 2005.

147. EPA. Risk Assessment Guidance for Superfund; Part E, Part F; EPA: Washington, DC, USA, 2011.

148. Li, Q.; Chen, Y.; Fu, H.; Cui, Z.; Shi, L.; Wang, L.; Liu, Z. Health risk of heavy metals in food crops grown on reclaimed tidal flat soil in the Pearl River Estuary, China. J. Hazard. Mater. 2012, 227, 148-154. [CrossRef]

149. Pandey, R.; Shubhashish, K.; Pandey, J. Dietary intake of pollutant aerosols via vegetables influenced by atmospheric deposition and wastewater irrigation. Ecotoxicol. Environ. Saf. 2012, 76, 200-208. [CrossRef]

150. Luo, C.; Liu, C.; Wang, Y.; Liu, X.; Li, F.; Zhang, G.; Li, X. Heavy metal contamination in soils and vegetables near an e-waste processing site, south China. J. Hazard. Mater. 2011, 186, 481-490. [CrossRef] [PubMed]

151. Singh, A.; Sharma, R.K.; Agrawal, M.; Marshall, F.M. Risk assessment of heavy metal toxicity through contaminated vegetables from waste water irrigated area of Varanasi, India. J. Trop. Ecol. 2010, 51, 375-387.

152. US Environmental Protection Agency (USEPA). Region 9, Preliminary Remediation Goals; USEPA: Washington, DC, USA, 2002.

153. Wang, H.; Dong, Y.H.; Li, D.C.; An, Q. Nutrient variation in plastic greenhouse soils with the years of cultivation. Soils 2005, 37, 460-466. (In Chinese)

154. Begum, A. Concurrent removal and accumulation of $\mathrm{Fe}^{2+}, \mathrm{Cd}^{2+}$ and $\mathrm{Cu}^{2+}$ from waste water using aquatic macrophytes. Der Pharma Chem. 2009, 1, 219-224.

155. Harrison, R.M.; Chirgawi, M.B. The assessment of air and soil as contributors of some trace metals to vegetable plants. III. Experiments with field-grown plants. Sci. Total Environ. 1989, 83, 47-62. [CrossRef]

156. United States Environmental Protection Agency (USEPA). USEPA Regional Screening Level (RSL) Summary Table; USEPA: Washington, DC, USA, 2011.

157. World Health Organization (WHO). Evaluation of Certain Food Additives and Contaminants; 41st Report of the Joint FAO/WHO Expert Committee on Food Additives; WHO Technical Report Series: 837; WHO: Geneva, Switzerland, 1993 ; p. 8.

158. United States Environmental Protection Agency (USEPA). Integrated Risk Information System-Database; USEPA: Washington, DC, USA, 2007.

159. Chien, L.; Hung, T.; Choang, K.; Yeh, C.; Meng, P.; Shieh, M.; Han, B. Daily intake of TBT, Cu, Zn, Cd and As for fishermen in Taiwan. Sci. Total Environ. 2002, 285, 177-185. [CrossRef]

160. Yang, Q.; Xu, Y.; Liu, S.; He, J.; Long, F. Concentration and potential health risk of heavy metals in market vegetables in Chongqing, China. Ecotoxicol. Environ. Saf. 2011, 74, 1664-1669. [CrossRef] [PubMed]

161. Fang, Y.; Nie, Z.; Liu, F.; Die, Q.; He, J.; Huang, Q. Concentration and health risk evaluation of heavy metals in market-sold vegetables and fishes based on questionnaires in Beijing, China. Environ. Sci. Pollut. Res. 2014, 21, 11401-11408. [CrossRef] [PubMed]

162. Copat, C.; Arena, G.; Fiore, M.; Ledda, C.; Fallico, R.; Sciacca, S.; Ferrante, M. Heavy metals concentrations in fish and shellfish from eastern Mediterranean Sea: Consumption advisories. Food Chem. Toxicol. 2013, 53, 33-37. [CrossRef] [PubMed]

163. Al-Saleh, I.; Nester, M.; Devol, E.; Shinwari, N.; Al-Shahria, S. Determinants of Blood Lead Levels in Saudi Arabian Schoolgirls. Int. J. Occup. Environ. Health 1999, 5, 107-114. [CrossRef]

164. Wang, L.; Ma, L.; Yang, Z. Spatial variation and risk assessment of heavy metals in paddy rice from Hunan Province, Southern China. Int. J. Environ. Sci. Technol. 2017, 15, 1561-1572. [CrossRef]

165. Horiguchi, H.; Oguma, E.; Sasaki, S.; Miyamoto, K.; Ikeda, Y.; Machida, M.; Kayama, F. Dietary exposure to cadmium at close to the current provisional tolerable weekly intake does not affect renal function among female Japanese farmers. Environ. Res. 2004, 95, 20-31. [CrossRef]

166. Cao, S.; Duan, X.; Zhao, X.; Wang, B.; Ma, J.; Fan, D.; Sun, C.; He, B.; Wei, F.; Jiang, G. Health risk assessment of various metal (loid)s via multiple exposure pathways on children living near a typical lead-acid battery plant, China. Environ. Pollut. 2015, 200, 16-23. [CrossRef]

167. Praveena, S.; Omar, N. Heavy metal exposure from cooked rice grain ingestion and its potential health risks to humans from total and bioavailable forms analysis. Food Chem. 2017, 235, 203-211. [CrossRef]

168. Silins, I.; Hogberg, J. Combined toxic exposures and human health: Biomarkers of exposure and effect. Int. J. Environ. Res. Public Health 2011, 8, 629-647. [CrossRef] [PubMed]

169. Fu, Q.; Li, L.; Achal, V.; Jiao, A.; Liu, Y. Concentrations of Heavy Metals and Arsenic in Market Rice Grain and Their Potential Health Risks to the Population of Fuzhou, China. Hum. Ecol. Risk Assess. 2015, 21, 117-128. [CrossRef]

170. US Environmental Protection Agency (USEPA). Risk Assessment Guidance for Superfund: Human Health Evaluation Manual [Part A]: Interim Final; EPA/540/1-89/002; US Environmental Protection Agency: Washington, DC, USA, 1989.

171. Ma, L.; Wang, L.; Jia, Y.; Yang, Z. Arsenic speciation in locally grown rice grains from Hunan Province, China: Spatial distribution and potential health risk. Sci. Total Environ. 2016, 557, 438-444. [CrossRef] [PubMed]

172. Wongsasuluk, P.; Chotpantarat, S.; Siriwong, W.; Robson, M. Heavy metal contamination and human health risk assessment in drinking water from shallow groundwater wells in an agricultural area in Ubon Ratchathani province, Thailand. Environ. Geochem. Health 2014, 36, 169-182. [CrossRef] [PubMed] 
173. Fakhri, Y.; Bjørklund, G.; Bandpei, A.M.; Chirumbolo, S.; Keramati, H.; Hosseini-Pouya, R.; Ghasemi, S.M. Concentrations of arsenic and lead in rice (Oryza sativa L.) in Iran: A systematic review and carcinogenic risk assessment. Food Chem. Toxicol. 2018, 113, 267-277. [CrossRef] [PubMed]

174. Omar, N.; Praveena, S.; Aris, A.; Hashim, Z. Health Risk Assessment using in vitro digestion model in assessing bioavailability of heavy metal in rice: A preliminary study. Food Chem. 2015, 188, 46-50. [CrossRef]

175. Zulkafflee, N.S.; Mohd Redzuan, N.A.; Hanafi, Z.; Selamat, J.; Ismail, M.R.; Praveena, S.M.; Abdull Razis, A.F. Heavy metal in paddy soil and its bioavailability in rice using in vitro digestion model for health risk assessment. Int. J. Environ. Res. Public Health 2019, 16, 4769. [CrossRef]

176. Peijnenburg, W.J.G.M.; Jager, T. Monitoring approaches to assess bioaccessibility and bioaccessible of metals: Matrix issues. Ecotoxicol. Environ. Saf. 2003, 56, 63-77. [CrossRef]

177. Fernández-García, E.; Carvajal-Lérida, I.; Pérez-Gálvez, A. In vitro bioaccessibility assessment as a prediction tool of nutritional efficiency. Nutr. Res. 2009, 29, 751-760. [CrossRef] [PubMed]

178. Lee, S.W.; Lee, B.T.; Kim, J.Y.; Kim, K.W.; Lee, J.S. Human risk assessment for heavy metals and as contamination in the abandoned metal mine areas, Korea. Environ. Monit. Assess. 2006, 119, 233-244. [CrossRef]

179. Devesa, V.; Vélez, D.; Montoro, R. Effect of thermal treatments on arsenic species contents in food. Food Chem. Toxicol. 2008, 46, 1-8. [CrossRef]

180. Zhang, J.Z. The Toxicity Assessment of Heavy Metals and Their Species in Rice. Ph.D. Thesis, University of Cincinnati, Cincinnati, OH, USA, 2009.

181. Yang, L.; Zhang, X.; Li, Y.; Li, H.; Wang, Y.; Wang, W. Bioaccessibility and Risk Assessment of Cadmium from Uncooked Rice Using an In Vitro Digestion Model. Biol. Trace Elem. Res. 2012, 145, 81-86. [CrossRef] [PubMed]

182. Malaysian Food Regulations. Food Act 1983 (Act 281): E Food Regulations 1985; International Law Book Services: Kuala Lumpur, Malaysia, 1985.

183. Abedin, M.J.; Cresser, M.S.; Meharg, A.A.; Feldmann, J.; Cotter-Howells, J. Arsenic Accumulation and Metabolism in Rice (Oryza sativa L.). Environ. Sci. Technol. 2002, 36, 962-968. [CrossRef]

184. Honma, T.; Ohba, H.; Kaneko-Kadokura, A.; Makino, T.; Nakamura, K.; Katou, H. Optimal soil Eh, pH, and water management for simultaneously minimizing arsenic and cadmium concentrations in rice grains. Environ. Sci. Technol. 2016, 50, 4178-4185. [CrossRef] [PubMed]

185. Guo, X.; Zhang, S.; Shan, X.; Luo, L.; Pei, Z.; Zhu, Y.; Liu, T.; Xie, Y.; Gault, A. Characterization of Pb, Cu and Cd adsorption on particulate organic matter in soil. Environ. Toxicol. Chem. 2006, 25, 2366-2373. [CrossRef]

186. Guo, G.; Zhou, Q.; Ma, L.Q. Availability and assessment of fixing additives for the in situ remediation of heavy metal contaminated soils: A review. Environ. Monit. Assess. 2006, 116, 513-528. [CrossRef]

187. Yan, Y.; Zhou, Y.Q.; Liang, C.H. Evaluation of phosphate fertilizers for the immobilization of Cd in contaminated soils. PLoS ONE 2015, 10, e0124022. [CrossRef] [PubMed]

188. Yu, L.L.; Zhu, J.Y.; Huang, Q.Q.; Su, D.C.; Jiang, R.E.; Li, H.F. Application of a rotation system to oilseed rape and rice fields in Cd-contaminated agricultural land to ensure food safety. Ecotoxicol. Environ. Saf. 2014, 108, 287-293. [CrossRef] [PubMed]

189. He, S.Y.; He, Z.L.; Yang, X.E.; Stoffella, P.J.; Baligar, V.C. Soil biogeochemistry, plant physiology, and phytoremediation of cadmium-contaminated soils. Adv. Agron. 2015, 134, 135-225.

190. Dixit, G.; Singh, A.P.; Kumar, A.; Singh, P.K.; Kumar, S.; Dwivedi, S.; Trivedi, P.K.; Pandey, V.; Norton, G.J.; Dhankher, O.P.; et al. Sulfur mediated reduction of arsenic toxicity involves efficient thiol metabolism and the antioxidant defense system in rice. J. Hazard. Mater. 2015, 298, 241-251. [CrossRef]

191. Takahashi, R.; lshimuru, Y.; Shimo, H.; Bashir, K.; Senoura, T.; Sugimoto, K.; Ono, K.; Suzui, N.; Kawachi, N.; Ishii, S.; et al. From laboratory to field: OsNRAMPS-knockdown rice is a promising candidate for Cd phytoremediation in paddy fields. PLoS ONE 2014, 9, e98816. [CrossRef]

192. Rinklebe, J.; Shaheen, S.M.; Frohne, T. Amendment of biochar reduces the release of toxic elements under dynamic redox conditions in a contaminated flood plain soil. Chemosphere 2016, 142, 41-47. [CrossRef] [PubMed]

193. Hu, P.J.; Ouyang, Y.N.; Wu, L.H.; Shen, L.B.; Luo, Y.M.; Christie, P. Effects of water management on arsenic and cadmium speciation and accumulation in an upland rice cultivar. J. Environ. Sci. 2015, 27, 225-231. [CrossRef]

194. Tanner, K.C.; Windham-Myers, L.; Marvin-Di-Pasquale, M.; Fleck, J.A.; Linquist, B.A. Alternate wetting and drying decreases methylmercury in flooded rice (Oryza sativa) systems. Soil Sci. Soc. Am. J. 2018, 82, 115-125. [CrossRef]

195. Wu, C.; Zou, Q.; Xue, S.G.; Pan, W.S.; Yue, X.; Hartley, W.; Huang, L.; Mo, J.Y. Effect of silicate on arsenic fractionation in soils and its accumulation in rice plants. Chemosphere 2016, 165, 478-486. [CrossRef]

196. Nwugo, C.; Huerta, A.J. Effects of silicon nutrition on cadmium-uptake, growth and photosynthesis of rice (Oryza sativa L.) seedlings exposed to long-term low-level cadmium. Plant Soil 2008, 311, 73-86. [CrossRef]

197. Liu, M.; Yang, Y.; Yun, X.; Zhang, M.; Wang, J. Concentrations, distribution, sources, and ecological risk assessment of heavy metals in agricultural topsoil of the Three Gorges Dam region, China. Environ. Monit. Assess. 2015, 187, 147. [CrossRef]

198. Suriyagoda, L.D.B.; Sirisena, D.N.; Somaweera, K.A.T.N.; Dissanayake, A.; de Costa, W.A.J.M.; Lambers, H. Incorporation of dolomite reduces iron toxicity, enhances growth and yield, and improves phosphorus and potassium nutrition in lowland rice (Oryza sativa L). Plant Soil 2017, 410, 299-312. [CrossRef] 
199. Gu, H.H.; Qiu, H.; Tian, T.; Zhan, S.S.; Deng, T.H.B.; Chaney, R.L.; Wang, S.Z.; Tang, Y.T.; Morel, J.L.; Qiu, R.L. Mitigation effects of silicon rich amendments on heavy metal accumulation in rice (Oryza sativa L.) planted on multi-metal contaminated acidic soil. Chemosphere 2011, 83, 1234-1240. [CrossRef] [PubMed]

200. Shaheen, S.M.; Rinklebe, J. Impact of emerging and low-cost alternative amendments on the (im)mobilization and phytoavailability of $\mathrm{Cd}$ and $\mathrm{Pb}$ in a contaminated floodplain soil. Ecol. Eng. 2015, 74, 319-326. [CrossRef]

201. Fan, J.; Xia, X.; Hu, Z.; Ziadi, N.; Liu, C. Excessive sulfur supply reduces arsenic accumulation in brown rice. Plant Soil Environ. 2013, 59, 169-174. [CrossRef]

202. Ahn, J.Y.; Kang, S.H.; Hwang, K.Y.; Kim, H.S.; Kim, J.G.; Song, H.; Hwang, I. Evaluation of phosphate fertilizers and red mud in reducing plant availability of $\mathrm{Cd}, \mathrm{Pb}$, and $\mathrm{Zn}$ in mine tailings. Environ. Earth Sci. 2015, 74, 2659-2668. [CrossRef]

203. Cao, X.; Ma, L.; Liang, Y.; Gao, B.; Harris, W. Simultaneous immobilization of lead and atrazine in contaminated soils using dairy manure biochar. Environ. Sci. Technol. 2011, 45, 4884-4889. [CrossRef] [PubMed]

204. Yu, Z.H.; Qiu, W.W.; Wang, F.; Lei, M.; Wang, D.; Song, Z.G. Effects of manganese oxide-modified biochar composites on arsenic speciation and accumulation in an indica rice (Oryza sativa L.) cultivar. Chemosphere 2017, 168, 341-349. [CrossRef]

205. Bian, R.; Chen, D.; Liu, X.; Cui, L.; Li, L.; Pan, G.; Xie, D.; Zheng, J.; Zhang, X.; Zheng, J. Biochar soil amendment as a solution to prevent Cd-tainted rice from China: Results from a cross-site field experiment. Ecol. Eng. 2013, 58, 378-383. [CrossRef]

206. Gao, X.P.; Brown, K.R.; Racz, G.J.; Grant, C.A. Concentration of cadmium in durum wheat as affected by time, source and placement of nitrogen fertilization under reduced and conventional-tillage management. Plant Soil 2010, 337, 341-354. [CrossRef]

207. Seregin, I.V.; Kozhevnikova, A.D.; Zhukovskaya, N.V.; Schat, H. Cadmium tolerance and accumulation in Excluder Thlaspi arvense and various accessions of hyperaccumulator Noccaea caerulescens. Russ. J. Plant Physiol. 2015, 62, 837-846. [CrossRef]

208. Wei, S.H.; Zeng, X.F.; Wang, S.S.; Zhu, J.G.; Ji, D.D.; Li, Y.M.; Jiao, H.J. Hyper accumulative property of Solanum nigrum L. to Cd explored from cell membrane permeability, subcellular distribution, and chemical form. J. Soils Sediments 2013, 14, 558-566. [CrossRef]

209. Ali, H.; Khan, E.; Sajad, M.A. Phytoremediation of heavy metals-concepts and applications. Chemosphere 2013, $91,869-881$. [CrossRef]

210. Zhang, X.; Lin, A.J.; Zhao, F.J.; Xu, G.Z.; Duan, G.L.; Zhu, Y.G. Arsenic accumulation by the aquatic fern Azolla: Comparison of arsenate uptake, speciation and efflux by A. caroliniana and A. filiculoides. Environ. Pollut. 2008, 156, 1149-1155. [CrossRef] [PubMed]

211. Li, H.; Luo, N.; Zhang, L.J.; Zhao, H.M.; Li, Y.W.; Cai, Q.Y.; Wong, M.H.; Mo, C.H. Do arbuscular mycorrhizal fungi affect cadmium uptake kinetics, subcellular distribution and chemical forms in rice? Sci. Total Environ. 2016, 571, 1183-1190. [CrossRef] [PubMed]

212. Chan, W.F.; Li, H.; Wu, F.Y.; Wu, S.C.; Wong, M.H. Arsenic uptake in upland rice inoculated with a combination or single arbuscular mycorrhizal fungi. J. Hazard. Mater. 2013, 262, 1116-1122. [CrossRef]

213. Falandysz, J.; Borovička, J. Macro and trace mineral constituents and radionuclides in mushrooms: Health benefits and risks. Appl. Microbiol. Biotechnol. 2013, 97, 477-501. [CrossRef]

214. Zhang, S.Y.; Zhao, F.J.; Sun, C.X.; Su, J.Q.; Yang, X.R.; Li, H.; Zhu, Y.G. Diversity and abundance of arsenic biotransformation genes in paddy soils from Southern China. Environ. Sci. Technol. 2015, 49, 4138-4146. [CrossRef] [PubMed]

215. Suriyagoda, L.D.B.; Dittert, K.; Lambers, H. Mechanism of arsenic uptake, translocation and plant resistance to accumulate arsenic in rice grains. Agric. Ecosyst. Environ. 2018, 253, 23-37. [CrossRef] 